\title{
Dynamika zmian cech somatycznych i sprawności fizycznej u dzieci uprawiających akrobatykę sportową
}

\section{The dynamic of the changes of the motoric features and physical fitness in the group of the children training the acrobatic}

The goal of that publication is to assess the tempo and dynamics of the basic somatic changes and physical fitness among young students - acrobats within 3 - year observation.

The source of the study are the results of the longitudinal research conducted in the primary sports school no 69 in Poznań. The children are trained there within 3 year program continuously. The research covers the students from the sports classes and the students from the ordinary classes, attending the same primary school.

The detailed analysis of the results shows, that the improved level of the sports activity, involving the systematic and dedicated physical training of the initial and basic acrobatics exercises does not considerably influence the differences of the tempo and the dynamic of the improvement of the certain physical features and physical fitness between the sports class students and control group.

\section{Wprowadzenie}

Ontogeneza wykazuje zróżnicowanie międzyosobnicze warunkowane genetycznie i ekologicznie. Tempo rozwoju może być szybsze lub wolniejsze, a wartości ostateczne cech mogą być większe lub mniejsze (Malinowski, Strzałko, 1985).

Cechami najszybciej reagującymi na jakiekolwiek ciągłe zmiany środowiska są cechy funkcjonalne, które stanowią pierwszy mechanizm adaptacyjny do nowych warunków otoczenia, w tym również aktywności fizycznej; są one jednocześnie dość labilne i w większości słabo uwarunkowane genetycznie (Szopa, Żak, 1986). 
Fenotyp jednostki w trakcie rozwoju zależy od genotypu, który w zasadzie w sposób bezpośredni i niezmienny determinuje cechy jakościowe, oraz od czynników środowiskowych, które modyfikująco wpływają na cechy ilościowe, które stanowią wypadkową oddziaływania czynników endo- i egzogennych (Malinowski, Strzałko, 1985). Proporcje działania tych czynników są bardzo labilne, a od siły, a także czasu trwania bodźców egzogennych, zależy stopień i kierunek odchylenia fenotypu (Wolański, 1983).

Zmiany biologiczne zachodzące w organizmie dziecka pod wpływem określonych form ruchowej aktywności są istotnie związane $z$ wiekiem ich podejmowania - są tym większe, im wcześniej, w młodszym wieku rozpoczyna się uprawianie specjalistycznych ćwiczeń fizycznych (Drozdowski Z., 2002).

Akrobatykę sportową zalicza są do tak zwanych „sportów wczesnych”, w których proces szkolenia sportowego może być przyspieszony nawet o dwa, trzy lata. Tak więc intensywny i specjalistyczny trening sportowy zbiega się z okresem wzmożonego wzrastania organizmu, okresem pokwitania. w których organizm dziecka wykazuje największą wrażliwość na działanie bodźców zewnętrznych (Ziemilska, 1984). Dlatego też zmiany modelowe treningu, wynikające między innymi $z$ bardzo wczesnego rozpoczynania szkolenia sportowego $w$ akrobatyce sportowej, jak również ciągłe próby doskonalenia i weryfikacji metod nauczania, powinny narzucać potrzebę wzmożenia wielokierunkowych badań, najlepiej longitudinalnych, które pozwoliłyby uchwycić istotne ogniwa procesu treningowego młodych akrobatów i akrobatek. Winny stanowić one istotny element w ustalaniu przesłanek do właściwego programowania procesu szkoleniowego, jak również eliminowania ujemnych skutków zwiększonej i ukierunkowanej aktywności ruchowej dzieci rozpoczynających systematyczne zajęcia sportowe.

Interesującym i ważnym zagadnieniem ontogenetycznym jest dynamika i tempo rozwoju poszczególnych cech somatycznych i sprawności fizycznej. Do oceny tempa i dynamiki wzrastania oraz dojrzewania dzieci i młodzieży najcenniejsze są badania ciągłe. Polegają one na kilkukrotnych pomiarach tych samego osób w równych odstępach czasu.

Celem autorek niniejszej pracy jest ocena dynamiki zmian podstawowych charakterystyk somatycznych i sprawności fizycznej młodych akrobatów i akrobatek w cyklu trzyletnich obserwacji.

\section{Materiał badawczy i metody badań}

Bazę empiryczną niniejszego opracowania stanowi materiał badawczy pochodzący z longitudinalnych badań dzieci, prowadzonych w sportowej Szkole Podstawowej nr 69 w Poznaniu, o profilu akrobatyki sportowej, w ciągu trzech kolejno następujących po sobie latach. Badaniami objęto uczniów z klas sportowych realizujących poszerzony program wychowania fizycznego i uczniów z klas równoległych tej samej szkoły uczestniczących w obligatoryjnej liczbie godzin wychowania fizycznego. $Z$ całości zgromadzonego materiału ciągłego wyselekcjonowano 
w każdym środowisku (sportowym i niesportowym) i dla każdej płci po cztery grupy dzieci, posiadających komplet pomiarów somatycznych i sprawności fizycznej ogólnej, wykonanych przez trzy kolejne lata.

Tabela 1. Charakterystyka liczbowa badanych

\begin{tabular}{|c|c|c|c|c|c|}
\hline \multirow{3}{*}{$\begin{array}{l}\text { Wyszczegól- } \\
\text { nienie }\end{array}$} & \multicolumn{4}{|c|}{ Wiek w latach } & \multirow{3}{*}{ Razem osób } \\
\hline & grupa 1 & grupa 2 & grupa 3 & grupa 4 & \\
\hline & 9-11 lat & 10-12 lat & $11-13$ lat & 12-14 lat & \\
\hline $\begin{array}{l}\text { Akrobaci - } \\
\text { (AC) }\end{array}$ & 13 & 7 & 13 & 7 & 40 \\
\hline $\begin{array}{l}\text { Akrobatki - } \\
\text { (AD) }\end{array}$ & 9 & 11 & 9 & 8 & 37 \\
\hline Chłopcy - (C) & 27 & 19 & 19 & 22 & 87 \\
\hline $\begin{array}{l}\text { Dziewczęta } \\
\text { - (D) }\end{array}$ & 27 & 29 & 26 & 21 & 103 \\
\hline
\end{tabular}

Źródło: badania własne.

Procedura badawcza obejmowała pomiary cech somatycznych i efektów ruchowych odzwierciedlających motoryczną komponentę sprawności fizycznej ogólnej.

Zmierzono: wysokość ciała, długość kończyny dolnej, długość tułowia, długość kończyny górnej, szerokość barków, szerokość klatki piersiowej, głębokość klatki piersiowej, szerokość bioder, obwód brzucha, obwód bioder, obwód ramienia, obwód uda, obwód podudzia największy, grubość fałdu skórno-tłuszczowego na plecach, grubość fałdu skórno-tłuszczowego na brzuchu, grubość fałdu skórno-tłuszczowego na ramieniu, grubość fałdu skórno-łłuszczowego pod kolanem oraz masę ciała.

Korzystając z pomiarów wymienionych cech wyznaczono wskaźnik BMI informujący o proporcjach wagowo-wzrostowych badanych dzieci (Drozdowski, 1998).

Badanie sprawności fizycznej ogólnej wykonano między innymi za pomocą wybranych prób sprawności fizycznej, wchodzących w skład Europejskiego Testu Sprawności Fizycznej (Grabowski, Szopa 1991), na podstawie którego określono: siłę funkcjonalną - czasem zwisu na drążku o ramionach ugiętych w nachwycie, siłę mięśni tułowia - liczbą poprawnie wykonanych w całości siadów z leżenia tyłem w czasie $1 / 2$ min, siłę eksplozywną - odległością skoku w dal obunóż z miejsca z pozycji stojącej, szybkość biegową i zwinność - czasem biegu wahadłowego $10 \times 5 \mathrm{~m}, \mathrm{z}$ maksymalną szybkością i zmianami kierunku ruchu. Za pomocą innych prób określono: gibkość - głębokością skłonu tułowia w przód o nogach wyprostowanych z postawy (Pawłucki, 1972), oraz skoczność - wysokością wyskoku dosiężnego obunóż z miejsca z pozycji stojącej (Drozdowski S., Drozdowski Z. 1975).

Dynamikę zmian rozwojowych zachodzących z wiekiem w badanych cechach somatycznych oceniono na podstawie bezwzględnych średnich przyrostów rocznych (p) (tabele 2-5), a także w skali wielkości unormowanych (tabela 6). Standaryzację wyników uzyskano, odnosząc przyrosty roczne badanych cech u dzieci uprawiających akrobatkę sportową do średniej arytmetycznej i średniego 
odchylenia standardowego rocznych przyrostów dzieci z klas kontrolnych. W celu porównania dynamiki rozwojowej różnych cech wyliczono również wskaźnik tempa rozwoju WTR ${ }_{\text {III }}$ (tabele $\left.7-10\right)$.

\section{Analiza wyników badań}

Dzieci uprawiające akrobatykę sportową niezależnie od tego, w którym roku rozpoczęły proces szkolenia sportowego, zawsze są przeciętnie niższe; wynika to z kierunkowego doboru dzieci do tej dyscypliny sportu. Nasuwa się jednak pytanie, jak kształtują się wielkości średnich rocznych przyrostów wysokości ciała w badanych zespołach.

Dynamika wzrastania wysokości ciała i jej składowych jest inna w zespole sportowym i niesportowym. Chłopcy uprawiający akrobatykę sportową charakteryzują się w młodszych grupach wieku pierwszej i drugiej przeciętnie niższymi rocznymi przyrostami wysokości ciała, aniżeli ich koledzy z klas kontrolnych. W starszych grupach trzeciej i czwartej dynamika wzrastania cechy jest już większa u akrobatów.

Zdecydowanie największą różnicę przyrastania wysokości ciała między porównywanymi zespołami zaobserwowano w trzeciej grupie między pierwszą i drugą serią badań.

Wzrastanie wysokości ciała w zespołach żeńskich kształtuje się na zbliżonym poziomie. Największe różnice zaobserwowano w pierwszej grupie między pierwszą i drugą serią badań na korzyść dziewcząt i w ostatniej najstarszej między drugą i trzecią serią na korzyść akrobatek.

Wzrastanie długości kończyn dolnych wskazuje na duże podobieństwo do scharakteryzowanych wcześniej zmian wysokości ciała.

Prawdopodobnie charakter przyrostów może być związany z występowaniem tzw. „szkolnego skoku wzrastania” (Malinowski, Strzałko 1985). U obu płci charakteryzuje się on zwiększeniem przyrostów rocznych, co prawdopodobnie związane jest ze wzrostem produkcji hormonów przez korę nadnerczy (Tanner, Cameron 1980). Należy jednak zwrócić uwagę, że zjawisko opisane powyżej w zespołach sportowych występuje nieco później niż w zespołach kontrolnych.

Dynamika wzrastania długości tułowia ma bardziej skokowy charakter niż to można było zaobserwować odnoście do wysokości ciała i długości kończyn dolnych. Przeciętnie wzrost długości tułowia u dzieci uprawiających akrobatykę sportową jest większy, niewykazujący większych podobieństw w rozwoju pozostałych cech wysokościowych.

Dzieci uprawiające akrobatykę sportową charakteryzuje względna stabilność wzrastania długości tułowia. Średnie roczne przyrosty tej cechy kształtują się na zbliżonym poziomie. Nie obserwujemy znacznych wzrostów czy też spadków przyrastania długości tułowia.

Dynamika wzrastania długości tułowia u dzieci z klas kontrolnych jest inna. Duże przyrosty tej cechy u chłopców przypadają na okres między 9 a 11 rokiem 
życia i później między 13 a 14 rokiem życia, a u dziewcząt między 10 a 12 rokiem życia. Odmienne tempo rozwoju długości tułowia chłopców i dziewcząt wpływa na kształtowanie się różnic płciowych.

Dynamika wzrastania długości kończyn górnych u dzieci uprawiających akrobatykę sportową i dzieci z klas porównawczych różni się znacząco. Akrobatów i akrobatki cechuje bardzo zróżnicowane tempo rocznych przyrostów. U dzieci obserwujemy względną stabilizację. Widoczny jest fakt, że u dzieci uprawiających akrobatykę sportową znacznie większe przyrosty występują między pierwszą i drugą serią badań. Wynikiem tego są większe przeciętne przyrosty tej cechy u dzieci z klas sportowych.

W przypadku cech wysokościowych u obu płci obserwujemy, że w młodszych grupach wieku średnie przyrosty roczne u akrobatów i akrobatek są mniejsze, a w starszych większe.

W wyniku dokonanej analizy średnich przyrostów rocznych rozpatrywanych cięciw tułowia zauważono, że dzieci uprawiające akrobatykę sportową w porównaniu z dziećmi z klas kontrolnych cechują się większą dynamiką wzrastania szerokości barków i bioder a niższą szerokości i głębokości klatki piersiowej.

Szerokość barków wykazuje zbliżony poziom rozwoju u dzieci obojga płci. Przeciętne przyrosty roczne są zdecydowanie większe u dzieci uprawiających akrobatykę sportową, zwłaszcza między pierwszą i drugą serią badań. Największe różnice $w$ przyrastaniu tej cechy odnotowano $w$ trzeciej i czwartej grupie u chłopców, a w drugiej i trzeciej u dziewcząt.

Wzrastanie szerokości klatki piersiowej wskazuje na bardzo duże podobieństwo do rozwoju głębokości klatki piersiowej. Średnie przyrosty tych cech są zdecydowanie większe u dzieci z klas kontrolnych. Zespoły męskie charakteryzują się nieco mniejszym zróżnicowaniem. Zespoły żeńskie wykazują większą odmienność zwłaszcza w dynamice rozwoju szerokości klatki piersiowej.

Szerokość bioder jest cechą, która w bardzo znaczący sposób odróżnia zespół sportowy od kontrolnego. Dzieci uprawiające akrobatykę sportową niezależnie od wieku i stażu treningowego charakteryzują się biodrami dość wąskimi. Z wiekiem różnice w rozwoju tej cechy między porównywanymi zespołami są coraz mniejsze, wskazując na fakt, że przyrastanie tej cechy jest większe u akrobatów i akrobatek niż u ich rówieśników z grup kontrolnych.

Przedmiotem kolejnych analiz były przeciętne przyrosty obwodów brzucha, bioder, ramienia i uda. Dynamika wzrastania obwodu brzucha, ramienia i uda jest większa u dzieci z klas porównawczych. Rozwój obwodu bioder charakteryzuje zbliżony poziom wykazujący tendencje do powiększania się różnic między badanymi zespołami sportowym i kontrolnym, na korzyść dzieci uprawiających akrobatykę sportową. Zauważyć należy jednak, że większe zróżnicowanie przyrostów obwodów ciała obserwujemy u dziewcząt.

Rozwój obwodów mięśniowych ramienia i uda u obu płci i grup porównawczych między 10 a 12 rokiem życia oraz 13 i 15 należy wiązać ze zwiększeniem umięśnienia (Tanner, Hughes, Whitehouse, 1981).

W toku dalszej analizy prześledzono różnice między dziećmi uprawiającymi akrobatykę sportową a ich rówieśnikami z klas równoległych w zakresie dynamiki 
zmian ontogenetycznych grubości fałdów skórno-tłuszczowych na brzuchu, plecach, ramieniu i pod kolanem. Różnice średnich przyrostów rocznych omawianych charakterystyk wykazują u akrobatów i akrobatek dość duże zróżnicowanie. Dzieci z klas kontrolnych wykazują względną stabilizację rozwoju tej cechy.

W zakresie dynamiki zmian ontogenetycznych grubości fałdów skórno-tłuszczowych na brzuchu, plecach, ramieniu i udzie, omawianych jako sumę fałdów, zaobserwowano u akrobatów i akrobatek, w przeciwieństwie do ich rówieśników, dość duże zróżnicowanie. Średnie przyrosty roczne sumy fałdów skórno-tłuszczowych w grupach sportowych u obu płci są zdecydowanie większe pomiędzy pierwszą i drugą serią badań. Jednakże $z$ wiekiem obserwuje się tendencję do pomniejszania się różnic pomiędzy grupami akrobatycznymi i kontrolnymi, zarówno u chłopców jak i u dziewcząt.

Dynamika wzrastania masy ciała wykazuje bardzo zbliżony poziom rozwoju u osobników obu płci. Przebieg zmian zachodzących z wiekiem w masie ciała jest zbliżony do odnotowanych wcześniej zmian w obwodach ciała. Największe przyrosty analizowanej cechy występują w zbliżonych okresach, w których następują znaczne przyrosty obwodów, zwłaszcza bioder, ramienia i uda - u chłopców między 11 a 13 rokiem życia, u dziewcząt między 11 a 15 rokiem życia. Chłopcy i dziewczęta z klas kontrolnych uzyskują przeciętnie większe przyrosty międzyrocznikowe masy ciała.

W objętym analizą przedziale wieku zarówno u chłopców, jak i u dziewcząt wyróżnić można tzw. okresy „pełnienia” i „bujania” organizmu. Zjawisko to jest ściśle związane ze zmianami zachodzącymi w zakresie przyrostów rocznych wysokości i masy ciała. Smuklenie sylwetki następuje w czasie przyspieszonych zmian rozwojowych wysokości ciała a obniżonych przyrostów masy ciała. Zaokrąglanie ciała, czyli tak zwane „pełnienie” organizmu, występuje w sytuacji odwrotnej, wówczas kiedy to odnotowuje się zwiększone tempo wzrastania masy ciała. Związane jest to $z$ odkładaniem się podskórnej tkanki tłuszczowej, której zapas zostanie zużyty w okresie „bujania”, związanego z przyspieszeniem zmian rozwojowych.

Wskaźnik względnej masy ciała Body Mass Index, uznawany za najbardziej użyteczny miernik, pozwala w prosty i skuteczny sposób obserwować dynamikę wzrastania wysokości i masy ciała, dając duże możliwości ciągłej kontroli prawidłowego rozwoju fizycznego dzieci.

Akrobatów cechuje dość zbliżony poziom zmian rozwoju wskaźnika między kolejnymi seriami badań, wskazujący tendencję do smuklenia organizmu wraz z wiekiem, w wyniku czego największe smuklenie wystąpiło w najstarszej grupie w wieku 14 lat. Chłopców charakteryzuje dość zróżnicowany poziom zmian analizowanego wskaźnika. We wszystkich grupach przeciętne wielkości wskaźnika między pierwszą a drugą serią badań są większe aniżeli między drugą a trzecią. $\mathrm{U}$ akrobatek i dziewcząt obserwujemy tendencję pełnienia organizmu. Średnie wielkości wskaźnika z wiekiem są większe. Zjawisko to wyraźniej widoczne jest u dziewcząt uprawiających akrobatykę sportową. 
Tabela 2. Ogólna charakterystyka statystyczna zmian (przyrostów) cech somatycznych u chłopców uprawiających akrobatykę sportową w poszczególnych grupach i seriach badań

\begin{tabular}{|c|c|c|c|c|c|c|c|c|c|}
\hline \multirow{3}{*}{\multicolumn{2}{|c|}{ Cechy somatyczne }} & \multicolumn{8}{|c|}{ Grupy akrobatów } \\
\hline & & \multicolumn{2}{|c|}{ AC1 } & \multicolumn{2}{|c|}{$\mathrm{AC2}$} & \multicolumn{2}{|c|}{ AC3 } & \multicolumn{2}{|c|}{ AC4 } \\
\hline & & $10-9$ & $10-11$ & $10-11$ & $12-11$ & $12-11$ & $13-12$ & $13-12$ & $14-13$ \\
\hline \multirow{2}{*}{ Wysokość ciała } & M & 4,49 & 4,17 & 4,49 & 4,07 & 5,08 & 6,38 & 4,94 & 6,97 \\
\hline & $S_{d}$ & 1,48 & 0,73 & 1,17 & 0,86 & 1,56 & 2,10 & 0,82 & 1,66 \\
\hline \multirow{2}{*}{$\begin{array}{l}\text { Długość kończy- } \\
\text { ny dolnej }\end{array}$} & $M$ & 2,82 & 2,96 & 2,99 & 3,10 & 3,36 & 4,24 & 3,49 & 4,00 \\
\hline & $S_{d}$ & 0,76 & 0,91 & 0,62 & 0,46 & 0,82 & 1,13 & 0,44 & 0,88 \\
\hline \multirow{2}{*}{ Długość tułowia } & $M$ & 1,12 & 1,08 & 0,98 & 0,62 & 1,19 & 1,09 & 0,83 & 1,68 \\
\hline & $S_{d}$ & 0,53 & 0,21 & 0,31 & 0,24 & 0,45 & 0,58 & 0,23 & 0,47 \\
\hline \multirow{2}{*}{$\begin{array}{l}\text { Długość kończy- } \\
\text { ny górnej }\end{array}$} & $M$ & 2,02 & 1,22 & 3,01 & 0,90 & 4,41 & 2,38 & 3,96 & 2,94 \\
\hline & $S_{d}$ & 1,94 & 1,01 & 1,50 & 1,49 & 2,41 & 1,37 & 1,74 & 1,63 \\
\hline \multirow{2}{*}{$\begin{array}{l}\text { Szerokość } \\
\text { barków }\end{array}$} & M & 1,31 & 0,73 & 1,36 & 0,93 & 1,35 & 0,92 & 1,86 & 1,29 \\
\hline & $S_{d}$ & 0,60 & 0,67 & 0,63 & 0,45 & 0,88 & 1,12 & 1,11 & 1,07 \\
\hline \multirow{2}{*}{$\begin{array}{l}\text { Szerokość klatki } \\
\text { piersiowej }\end{array}$} & $M$ & 0,58 & 0,81 & 0,93 & 0,71 & 0,77 & 1,00 & 0,71 & 1,57 \\
\hline & $S_{d}$ & 0,45 & 0,48 & 0,79 & 0,95 & 0,88 & 0,71 & 0,49 & 1,17 \\
\hline \multirow{2}{*}{$\begin{array}{l}\text { Głębokość klatki } \\
\text { piersiowej }\end{array}$} & $M$ & 0,42 & 0,65 & 0,57 & 0,64 & 0,92 & 0,54 & 0,64 & 0,93 \\
\hline & $S_{d}$ & 0,93 & 0,99 & 0,35 & 0,63 & 0,53 & 0,72 & 0,80 & 0,53 \\
\hline \multirow{2}{*}{ Szerokość bioder } & $M$ & 0,12 & 1,54 & 1,14 & 1,57 & 1,38 & 1,69 & 0,43 & 1,43 \\
\hline & $S_{d}$ & 0,94 & 0,85 & 0,90 & 0,61 & 0,77 & 1,36 & 0,89 & 1,74 \\
\hline \multirow{2}{*}{ Obwód brzucha } & $M$ & 1,42 & 1,54 & 2,50 & 2,14 & 1,42 & 3,85 & 2,43 & 2,86 \\
\hline & $S_{d}$ & 2,19 & 2,15 & 1,38 & 2,54 & 2,56 & 2,30 & 2,42 & 1,57 \\
\hline \multirow{2}{*}{ Obwód bioder } & $M$ & 3,00 & 2,96 & 3,00 & 3,00 & 3,31 & 4,50 & 4,36 & 4,35 \\
\hline & $S_{d}$ & 3,31 & 1,38 & 1,63 & 1,00 & 1,67 & 1,19 & 2,21 & 5,69 \\
\hline \multirow{2}{*}{ Obwód ramienia } & $M$ & 0,04 & 0,88 & 0,50 & 0,64 & 0,58 & 0,65 & 0,29 & 0,57 \\
\hline & $S_{d}$ & 1,05 & 0,51 & 0,91 & 0,38 & 0,57 & 0,88 & 1,55 & 0,84 \\
\hline \multirow{2}{*}{ Obwód uda } & $M$ & $-0,12$ & 1,27 & 1,71 & 0,79 & 0,42 & 2,00 & 1,14 & 0,71 \\
\hline & $S_{d}$ & 2,61 & 1,07 & 1,07 & 0,70 & 1,66 & 1,32 & 1,21 & 2,64 \\
\hline \multirow{2}{*}{ Obwód podudzia } & $M$ & 1,12 & 1,58 & 1,36 & 0,93 & 1,54 & 1,54 & 1,43 & 0,86 \\
\hline & $S_{d}$ & 0,89 & 0,64 & 0,56 & 0,61 & 0,75 & 1,01 & 0,79 & 1,11 \\
\hline \multirow{2}{*}{$\begin{array}{l}\text { Suma fałdów } \\
\text { skórno-tłuszczo- } \\
\text { wych }\end{array}$} & $M$ & 0,13 & $-0,05$ & 0,15 & $-0,10$ & 0,06 & 0,01 & 0,08 & $-0,02$ \\
\hline & $S_{d}$ & 0,08 & 0,06 & 0,10 & 0,06 & 0,06 & 0,10 & 0,12 & 0,08 \\
\hline \multirow{2}{*}{ Masa ciała } & $M$ & 2,73 & 3,21 & 3,34 & 2,89 & 3,72 & 5,43 & 4,34 & 4,67 \\
\hline & $\mathrm{S}_{d}$ & 1,86 & 0,83 & 0,79 & 0,72 & 1,25 & 2,19 & 1,50 & 2,64 \\
\hline \multirow{2}{*}{ Wskaźnik BMI } & $M$ & 0,47 & 0,74 & 0,76 & 0,50 & 0,62 & 0,95 & 0,78 & 0,33 \\
\hline & $S_{d}$ & 0,74 & 0,34 & 0,55 & 0,43 & 0,53 & 0,60 & 0,44 & 0,88 \\
\hline
\end{tabular}

Źródło: badania własne. 
Tabela 3. Ogólna charakterystyka statystyczna zmian (przyrostów) cech somatycznych u dziewcząt uprawiających akrobatykę sportową w poszczególnych grupach i seriach badań

\begin{tabular}{|c|c|c|c|c|c|c|c|c|c|}
\hline \multirow{3}{*}{\multicolumn{2}{|c|}{ Cechy somatyczne }} & \multicolumn{8}{|c|}{ Grupy akrobatek } \\
\hline & & \multicolumn{2}{|c|}{ AD1 } & \multicolumn{2}{|c|}{ AD2 } & \multicolumn{2}{|c|}{ AD3 } & \multicolumn{2}{|c|}{ AD4 } \\
\hline & & \multirow{3}{*}{$\begin{array}{l}10-9 \\
3,94 \\
1,42 \\
\end{array}$} & \multirow{3}{*}{$\begin{array}{c}10-11 \\
4,92 \\
1,51\end{array}$} & \multirow{3}{*}{$\begin{array}{c}10-11 \\
5,08 \\
1,20\end{array}$} & \multirow{3}{*}{$\begin{array}{c}\mathbf{1 2 - 1 1} \\
5,21 \\
1,10\end{array}$} & \multirow{3}{*}{$\begin{array}{c}12-11 \\
5,64 \\
1,19\end{array}$} & \multirow{3}{*}{$\begin{array}{c}\mathbf{1 3 - 1 2} \\
5,30 \\
1,23\end{array}$} & \multirow{3}{*}{$\begin{array}{c}\mathbf{1 3 - 1 2} \\
4,65 \\
2,35\end{array}$} & \multirow{3}{*}{$\begin{array}{c}\mathbf{1 4 - 1 3} \\
3,78 \\
2,13\end{array}$} \\
\hline Wucokoćó ciat & $M$ & & & & & & & & \\
\hline Vysokosc clała & $S_{d}$ & & & & & & & & \\
\hline \multirow{2}{*}{$\begin{array}{l}\text { Długość kończy- } \\
\text { ny dolnej }\end{array}$} & $M$ & 2,68 & 3,37 & 3,43 & 3,52 & 3,84 & 2,78 & 2,74 & 1,89 \\
\hline & $S_{d}$ & 0,72 & 0,79 & 0,63 & 0,60 & 0,66 & 0,65 & 1,24 & 1,13 \\
\hline \multirow{2}{*}{ Długość tułowia } & $\mathrm{M}$ & 1,01 & 1,28 & 1,37 & 1,00 & 0,89 & 1,53 & 1,20 & 1,18 \\
\hline & $S_{d}$ & 0,41 & 0,44 & 0,35 & 0,30 & 0,32 & 0,36 & 0,67 & 0,60 \\
\hline \multirow{2}{*}{$\begin{array}{l}\text { Długość kończy- } \\
\text { ny górnej }\end{array}$} & $M$ & 1,34 & 2,72 & 2,87 & 1,38 & 3,46 & 2,03 & 3,65 & 2,38 \\
\hline & $S_{d}$ & 2,08 & 1,42 & 1,40 & 0,84 & 1,84 & 1,71 & 3,09 & 3,04 \\
\hline \multirow{2}{*}{$\begin{array}{l}\text { Szerokość } \\
\text { barków }\end{array}$} & $\mathrm{M}$ & 0,67 & 1,50 & 1,95 & 1,05 & 1,89 & 0,89 & 1,40 & 1,31 \\
\hline & $S_{d}$ & 1,09 & 1,25 & 1,72 & 0,76 & 1,02 & 0,78 & 1,51 & 2,33 \\
\hline \multirow{2}{*}{\begin{tabular}{|l|} 
Szerokość klatki \\
piersiowej
\end{tabular}} & $\mathrm{M}$ & 0,28 & 0,89 & 0,64 & 1,09 & 0,44 & 1,22 & 0,00 & 0,69 \\
\hline & $S_{d}$ & 0,57 & 0,74 & 0,64 & 0,94 & 1,01 & 0,94 & 1,93 & 1,13 \\
\hline \multirow{2}{*}{$\begin{array}{l}\begin{array}{l}\text { Głębokość klatki } \\
\text { piersiowej }\end{array} \\
\end{array}$} & $M$ & 0,28 & 0,89 & 0,91 & 0,68 & 0,50 & 0,44 & 0,43 & 0,88 \\
\hline & $S_{d}$ & 0,44 & 0,55 & 0,70 & 0,68 & 0,71 & 0,68 & 0,42 & 0,92 \\
\hline \multirow{2}{*}{$\begin{array}{l}\text { Szerokość } \\
\text { bioder }\end{array}$} & $M$ & 1,39 & 2,50 & 1,09 & 1,55 & 1,50 & 1,83 & 0,53 & 1,75 \\
\hline & $S_{d}$ & 1,64 & 1,03 & 1,07 & 0,57 & 0,43 & 0,87 & 1,55 & 1,65 \\
\hline \multirow{2}{*}{ Obwód brzucha } & $M$ & 0,67 & 1,44 & $-0,09$ & 2,36 & 1,5 & 1,5 & 0,50 & 1,50 \\
\hline & $S_{d}$ & 2,55 & 1,51 & 2,31 & 1,96 & 1,43 & 1,77 & 2,35 & 3,07 \\
\hline \multirow{2}{*}{ Obwód bioder } & $M$ & 2,72 & 2,83 & 3,14 & 3,27 & 5,00 & 4,78 & 3,38 & 5,63 \\
\hline & $S_{d}$ & 1,89 & & 1,10 & 1,35 & 2,63 & 1,86 & 1,51 & 2,33 \\
\hline \multirow{2}{*}{ Obwód ramienia } & $M$ & $-0,06$ & 0,50 & 0,77 & $-0,05$ & 0,61 & 0,94 & 0,13 & 0,94 \\
\hline & $S_{d}$ & 0,81 & 0,50 & 0,93 & 0,72 & 0,49 & 0,68 & 0,79 & 0,78 \\
\hline \multirow{2}{*}{ Obwód uda } & $M$ & 1,11 & 1,78 & 0,58 & 0,96 & 1,72 & 2,44 & 0,75 & 2,81 \\
\hline & $S_{d}$ & 2,09 & 1,79 & 1,76 & 1,64 & 2,03 & 1,72 & 1,93 & 2,71 \\
\hline \multirow{2}{*}{ Obwód podudzia } & $M$ & 1,00 & 1,56 & 1,45 & 0,91 & 1,44 & 1,39 & 0,94 & 1,31 \\
\hline & $S_{d}$ & 0,90 & 0,95 & 0,93 & 0,97 & 1,07 & 0,70 & 0,50 & 0,84 \\
\hline \multirow{2}{*}{$\begin{array}{l}\text { Suma fałdów } \\
\text { skórno-tłuszczo- } \\
\text { wych }\end{array}$} & M & 0,06 & $-0,03$ & 0,07 & $-0,03$ & 0,08 & 0,01 & 0,09 & 0,05 \\
\hline & $\mathrm{S}_{\mathrm{d}}$ & 0,05 & 0,09 & 0,06 & 0,06 & 0,06 & 0,06 & 0,07 & 0,09 \\
\hline & $M$ & 3,18 & 3,03 & 3,15 & 3,20 & 3,87 & 5,37 & 3,55 & 5,91 \\
\hline Masa ciała & $S_{d}$ & 2,35 & 1,21 & 1,08 & 1,84 & 1,98 & 2,28 & 1,46 & 1,96 \\
\hline & $M$ & 0,95 & 0,53 & 0,52 & 0,40 & 0,55 & 1,15 & 0,53 & 1,55 \\
\hline Wskaźnik B & $S_{d}$ & 1,25 & 0,54 & 0,39 & 0,70 & 0,63 & 0,95 & 0,50 & 0,48 \\
\hline
\end{tabular}

Źródło: badania własne. 
Tabela 4. Ogólna charakterystyka statystyczna zmian (przyrostów) cech somatycznych u chłopców klas porównawczych w poszczególnych grupach i seriach badań

\begin{tabular}{|c|c|c|c|c|c|c|c|c|c|}
\hline \multirow{3}{*}{\multicolumn{2}{|c|}{ Cechy somatyczne }} & \multicolumn{8}{|c|}{ Grupy chłopców } \\
\hline & & \multicolumn{2}{|c|}{ C1 } & \multicolumn{2}{|c|}{$\mathrm{C} 2$} & \multicolumn{2}{|c|}{ C3 } & \multicolumn{2}{|c|}{ C4 } \\
\hline & & \multirow{3}{*}{$\begin{array}{l}10-9 \\
5,22 \\
0,96 \\
\end{array}$} & \multirow{3}{*}{$\begin{array}{c}\mathbf{1 0 - 1 1} \\
5,01 \\
1,47\end{array}$} & \multirow{3}{*}{$\begin{array}{c}\mathbf{1 0 - 1 1} \\
5,36 \\
1,03\end{array}$} & \multirow{3}{*}{$\begin{array}{c}12-11 \\
5,75 \\
1,55\end{array}$} & \multirow{3}{*}{$\begin{array}{c}12-11 \\
2,83 \\
1,11\end{array}$} & \multirow{3}{*}{$\begin{array}{c}\mathbf{1 3 - 1 2} \\
5,24 \\
1,91\end{array}$} & \multirow{3}{*}{$\begin{array}{c}13-12 \\
4,39 \\
1,37\end{array}$} & \multirow{3}{*}{\begin{tabular}{r|}
$\mathbf{1 4 - 1 3}$ \\
6,44 \\
2,20
\end{tabular}} \\
\hline Wvyso & $M$ & & & & & & & & \\
\hline Vvyso & $S_{d}$ & & & & & & & & \\
\hline \multirow{2}{*}{$\begin{array}{l}\text { Długość kończy- } \\
\text { ny dolnej }\end{array}$} & $M$ & 3,24 & 3,32 & 3,36 & 4,37 & 2,54 & 3,56 & 2,96 & 3,60 \\
\hline & $S_{d}$ & 0,50 & 0,76 & 0,53 & 0,83 & 0,58 & 1,02 & 0,74 & 1,17 \\
\hline \multirow{2}{*}{ Długość tułowia } & $M$ & 1,50 & 1,15 & 1,83 & 0,43 & 0,20 & 0,70 & 0,78 & 1,77 \\
\hline & $S_{d}$ & 0,28 & 0,42 & 0,30 & 0,43 & 0,32 & 0,53 & 0,38 & 0,64 \\
\hline \multirow{2}{*}{$\begin{array}{l}\text { Długość kończy- } \\
\text { ny górnej }\end{array}$} & $M$ & 2,37 & 2,00 & 2,26 & 2,59 & 2,34 & 1,72 & 2,23 & 3,22 \\
\hline & $S_{d}$ & 0,53 & 1,45 & 0,97 & 1,69 & 1,08 & 1,00 & 0,79 & 1,91 \\
\hline \multirow{2}{*}{$\begin{array}{l}\text { Szerokość } \\
\text { barków }\end{array}$} & $M$ & 0,78 & 0,61 & 1,05 & 1,71 & 0,82 & 1,18 & 0,82 & 1,32 \\
\hline & $S_{d}$ & 0,38 & 0,79 & 0,64 & 1,54 & 0,34 & 1,28 & 0,55 & 1,23 \\
\hline \multirow{2}{*}{$\begin{array}{l}\text { Szerokość klatki } \\
\text { piersiowej }\end{array}$} & $M$ & 0,89 & 1,15 & 0,95 & 1,16 & 0,87 & 0,79 & 0,93 & 0,98 \\
\hline & $S_{d}$ & 0,61 & 0,81 & 0,52 & 0,76 & 0,44 & 0,75 & 0,44 & 1,61 \\
\hline \multirow{2}{*}{$\begin{array}{l}\text { Głębokość klatki } \\
\text { piersiowej }\end{array}$} & $M$ & 0,63 & 0,80 & 0,87 & 1,08 & 0,76 & 0,92 & 0,93 & 1,11 \\
\hline & $S_{d}$ & 0,38 & 0,67 & 0,44 & 0,63 & 0,26 & 0,61 & 0,47 & 0,89 \\
\hline \multirow{2}{*}{$\begin{array}{l}\text { Szerokość } \\
\text { bioder }\end{array}$} & $M$ & 0,80 & 0,63 & 0,53 & 1,29 & 0,89 & 1,00 & 0,89 & 1,32 \\
\hline & $S_{d}$ & 0,25 & 0,36 & 0,39 & 0,67 & 0,43 & 0,41 & 0,21 & 0,57 \\
\hline \multirow{2}{*}{ Obwód brzucha } & $M$ & 3,37 & 3,26 & 2,53 & 3,05 & 2,53 & 2,63 & 3,23 & 3,32 \\
\hline & $S_{d}$ & 1,39 & 2,80 & 3,55 & 3,34 & 2,04 & 2,73 & 2,16 & 2,63 \\
\hline \multirow{2}{*}{ Obwód bioder } & $M$ & 3,00 & 3,41 & 2,89 & 3,63 & 2,95 & 3,84 & 3,64 & 4,55 \\
\hline & $S_{d}$ & 1,52 & 2,37 & 1,76 & 2,63 & 1,81 & 1,95 & 1,92 & 1,77 \\
\hline \multirow{2}{*}{ Obwód ramienia } & $M$ & 0,76 & 0,80 & 0,87 & 0,92 & 0,66 & 0,74 & 0,93 & 0,93 \\
\hline & $S_{d}$ & 0,47 & 0,90 & 0,37 & 1,32 & 0,24 & 0,59 & 0,68 & 0,71 \\
\hline \multirow{2}{*}{ Obwód uda } & $M$ & 1,98 & 1,63 & 1,79 & 1,11 & 1,45 & 1,68 & 1,59 & 1,66 \\
\hline & $S_{d}$ & 1,21 & 1,89 & 1,17 & 1,37 & & 1,17 & 0,83 & 1,67 \\
\hline \multirow{2}{*}{ Obwód podudzia } & $M$ & 1,00 & 1,02 & 0,74 & 1,11 & 0,61 & 1,21 & 0,75 & 1,14 \\
\hline & $S_{d}$ & 0,54 & 106 & 0,67 & 0,84 & 0,57 & 0,80 & 0,53 & 0,80 \\
\hline \multirow{2}{*}{$\begin{array}{l}\text { Suma fałdów } \\
\text { skórno-tłuszczo- } \\
\text { wych }\end{array}$} & $M$ & 0,03 & 0,00 & 0,03 & 0,00 & 0,02 & 0,01 & 0,03 & $-0,02$ \\
\hline & $S_{d}$ & 0,02 & 0,07 & $\begin{array}{c}, 02 \\
02\end{array}$ & 0,05 & 0,02 & 0,05 & 0,03 & 0,06 \\
\hline & $M$ & 4,50 & 3,73 & 6,01 & 4,45 & 2,80 & 4,07 & 5,16 & 4,98 \\
\hline & $S_{d}$ & 1,34 & 2,08 & 1,30 & 2,82 & 1,02 & 2,39 & 0,65 & 3,21 \\
\hline & $M$ & 1,03 & 0,51 & 1,52 & 0,49 & 0,55 & 0,44 & 1,06 & 0,38 \\
\hline W & $S_{d}$ & 0,85 & 0,72 & 0,80 & 1,19 & 0,55 & 0,75 & 0,58 & 1,06 \\
\hline
\end{tabular}

Źródło: badania własne. 
Tabela 5. Ogólna charakterystyka statystyczna zmian (przyrostów) cech somatycznych u dziewcząt klas porównawczych w poszczególnych grupach i seriach badań

\begin{tabular}{|c|c|c|c|c|c|c|c|c|c|}
\hline \multirow{3}{*}{\multicolumn{2}{|c|}{ Cechy somatyczne }} & \multicolumn{8}{|c|}{ Grupy dziewcząt } \\
\hline & & \multicolumn{2}{|c|}{ D1 } & \multicolumn{2}{|c|}{ D2 } & \multicolumn{2}{|c|}{ D3 } & \multicolumn{2}{|c|}{ D4 } \\
\hline & & \multirow{3}{*}{$\begin{array}{l}\mathbf{1 0 - 9} \\
5,46 \\
1,27 \\
\end{array}$} & \multirow{3}{*}{$\begin{array}{c}10-11 \\
5,11 \\
1,70 \\
\end{array}$} & \multirow{3}{*}{$\begin{array}{c}\mathbf{1 0 - 1 1} \\
4,91 \\
0,91\end{array}$} & \multirow{3}{*}{$\begin{array}{c}\mathbf{1 2 - 1 1} \\
5,56 \\
1,37 \\
\end{array}$} & \multirow{3}{*}{$\begin{array}{c}12-11 \\
5,55 \\
1,72 \\
\end{array}$} & \multirow{3}{*}{$\begin{array}{c}13-12 \\
4,89 \\
2,02 \\
\end{array}$} & \multirow{3}{*}{$\begin{array}{c}13-12 \\
4,70 \\
1,73 \\
\end{array}$} & \multirow{3}{*}{\begin{tabular}{r|}
$14-13$ \\
2,62 \\
1,04 \\
\end{tabular}} \\
\hline Wucokoćć ciata & $M$ & & & & & & & & \\
\hline Wysokosc clara & $S_{d}$ & & & & & & & & \\
\hline \multirow{2}{*}{$\begin{array}{l}\text { Długość kończy- } \\
\text { ny dolnej }\end{array}$} & $M$ & 3,53 & 3,99 & 3,74 & 3,40 & 3,10 & 2,92 & 2,82 & 1,40 \\
\hline & $S_{d}$ & 0,66 & 0,91 & 0,49 & 0,72 & 0,91 & 1,07 & 0,92 & 0,56 \\
\hline \multirow{2}{*}{ Długość tułowia } & $M$ & 0,18 & 0,93 & 0,81 & 1,41 & 1,55 & 1,20 & 1,15 & 1,89 \\
\hline & $S_{d}$ & 0,57 & 0,80 & 0,26 & 0,38 & 0,48 & 0,56 & 0,48 & 0,29 \\
\hline \multirow{2}{*}{$\begin{array}{l}\text { Długość kończy- } \\
\text { ny górnej }\end{array}$} & $M$ & 2,91 & 1,98 & 2,02 & 2,84 & 2,44 & 2,62 & 2,17 & 1,80 \\
\hline & $S_{d}$ & 1,73 & 1,75 & 0,89 & 1,58 & 1,04 & 1,42 & 0,97 & 1,15 \\
\hline \multirow{2}{*}{\begin{tabular}{|l} 
Szerokość \\
barków
\end{tabular}} & $M$ & 0,98 & 1,04 & 0,98 & 0,74 & 0,79 & 1,04 & 0,93 & 0,69 \\
\hline & $S_{d}$ & 0,40 & 0,60 & 0,53 & 0,62 & 0,53 & 1,37 & 0,36 & 0,94 \\
\hline \multirow{2}{*}{$\begin{array}{l}\text { Szerokość klatki } \\
\text { piersiowej }\end{array}$} & $M$ & 0,83 & 1,20 & 0,88 & 1,22 & 0,83 & 1,37 & 0,90 & 1,02 \\
\hline & $S_{d}$ & 0,54 & 0,65 & 0,45 & 0,65 & 0,31 & 0,71 & 0,34 & 0,70 \\
\hline \multirow{2}{*}{$\begin{array}{l}\text { Głębokość klatki } \\
\text { piersiowej }\end{array}$} & $M$ & 0,96 & 0,85 & 0,95 & 0,84 & 0,67 & 0,35 & 1,02 & 0,86 \\
\hline & $S_{d}$ & 0,44 & 0,48 & 0,45 & 0,68 & 0,31 & 0,63 & 0,40 & 0,69 \\
\hline \multirow{2}{*}{$\begin{array}{l}\begin{array}{l}\text { Szerokość } \\
\text { bioder }\end{array} \\
\end{array}$} & $M$ & 0,89 & 0,83 & 0,98 & 1,16 & 0,75 & 0,63 & 0,71 & 1,21 \\
\hline & $S_{d}$ & 0,51 & 0,42 & 0,49 & 0,42 & 0,32 & 0,33 & 0,60 & 0,89 \\
\hline \multirow{2}{*}{ Obwód brzucha } & $M$ & 2,85 & 2,93 & 2,93 & 3,66 & 2,08 & 1,96 & 2,38 & 2,00 \\
\hline & $S_{d}$ & 1,61 & 3,51 & 1,67 & 2,83 & 1,38 & 2,34 & 1,43 & 2,79 \\
\hline \multirow{2}{*}{ Obwód bioder } & $M$ & 2,15 & 3,30 & 3,07 & 4,97 & 2,85 & 3,73 & 2,48 & 3,05 \\
\hline & $S_{d}$ & 1,81 & 2,70 & 1,79 & 2,65 & 1,43 & 3,04 & 1,50 & 1,96 \\
\hline \multirow{2}{*}{ Obwód ramienia } & $M$ & 0,83 & 0,67 & 0,90 & 0,91 & 0,44 & 0,75 & 1,00 & 0,98 \\
\hline & $\mathrm{S}_{\mathrm{d}}$ & 0,50 & 0,78 & 0,47 & 0,64 & 0,75 & 0,89 & 0,52 & 1,10 \\
\hline \multirow{2}{*}{ Obwód uda } & $M$ & 1,78 & 1,87 & 1,17 & 2,45 & 1,58 & 1,65 & 1,93 & 1,95 \\
\hline & $S_{d}$ & 0,71 & 2,42 & 0,50 & 1,16 & 0,76 & 2,22 & 0,83 & 1,47 \\
\hline \multirow{2}{*}{ Obwód podudzia } & $M$ & 0,69 & 1,04 & 0,29 & 1,57 & 0,77 & 1,00 & 0,64 & 0,74 \\
\hline & $S_{d}$ & 0,50 & 0,77 & 1,88 & 1,86 & 0,59 & 1,04 & 0,64 & 0,78 \\
\hline \multirow{2}{*}{$\begin{array}{l}\text { Suma fałdów } \\
\text { skórno-tłuszczo- } \\
\text { wych }\end{array}$} & $M$ & 0,04 & 0,03 & 0,03 & 0,02 & 0,03 & 0,01 & 0,04 & 0,02 \\
\hline & $S_{d}$ & 0,02 & 0,07 & 0,02 & 0,05 & 0,02 & 0,06 & 0,03 & 0,06 \\
\hline Maca ciała & $M$ & 3,28 & 5,04 & 3,88 & 5,21 & 4,26 & 4,26 & 4,80 & 3,44 \\
\hline Miasa clała & $S_{d}$ & 1,04 & 2,08 & 1,21 & 1,66 & 1,31 & 3,08 & 1,40 & 1,67 \\
\hline & $M$ & 0,43 & 1,20 & 0,66 & 0,98 & 0,58 & 0,63 & 0,83 & 0,69 \\
\hline Wskaźnik BMI & $S_{d}$ & 0,70 & 0,77 & 0,75 & 0,77 & 0,76 & 1,24 & 0,62 & 0,58 \\
\hline
\end{tabular}

Źródło: badania własne. 


\begin{tabular}{|c|c|c|c|c|c|c|c|c|c|c|c|c|c|c|c|c|c|c|c|}
\hline$\frac{\pi}{\frac{\pi}{0}} \cdot \frac{3}{\frac{0}{0}} \frac{\pi}{\frac{\pi}{0}}$ & I & $\mid \begin{array}{c}\tilde{m} \\
\stackrel{-}{1}\end{array}$ & $\left|\begin{array}{l}2 \\
2 \\
0 \\
0 \\
1\end{array}\right|$ & 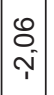 & $\begin{array}{l}10 \\
0 \\
0 \\
1\end{array}$ & $\begin{array}{l}8 \\
\text { o } \\
\circ\end{array}$ & $\begin{array}{l}1 \\
0 \\
0 \\
0\end{array}$ & $\frac{\stackrel{\mathscr{N}}{N}}{\leftarrow}$ & 웅 & & $\nabla$ & 웅 & $\begin{array}{l}8 \\
8 \\
0 \\
1\end{array}$ & $\begin{array}{l}\overline{6} \\
0 \\
1\end{array}$ & $\mid \begin{array}{l}\bar{N} \\
\overline{1}\end{array}$ & $\begin{array}{l}0 \\
0 \\
0 \\
1\end{array}$ & $\mid \begin{array}{l}0 \\
m \\
0 \\
0\end{array}$ & $\begin{array}{l}8 \\
0 \\
1\end{array}$ & $\stackrel{\infty}{=}$ \\
\hline$\frac{\pi}{\square} \sum$ & $m$ & 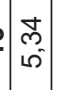 & $\hat{0}$ & \begin{tabular}{|l|} 
\\
0 \\
0
\end{tabular} & $\frac{\mathscr{m}}{\leftarrow}$ & 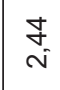 & $\stackrel{\infty}{\leftarrow}$ & $\stackrel{m}{m}$ & $\begin{array}{l}0 \\
0 \\
0 \\
1\end{array}$ & & $\stackrel{m}{\sim}$ & $\begin{array}{l}\infty \\
m \\
\sim\end{array}$ & $\begin{array}{l}\bar{\sigma} \\
0 \\
\end{array}$ & $\stackrel{\infty}{N}$ & $\begin{array}{l}8 \\
\\
\\
\end{array}$ & 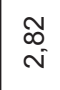 & $\begin{array}{l}0 \\
0 \\
0 \\
1\end{array}$ & $\frac{n}{i}$ & 晸 \\
\hline बू & N & $\left|\begin{array}{c}0 \\
\\
\end{array}\right|$ & $\left|\begin{array}{l}0 \\
0 \\
0 \\
1\end{array}\right|$ & $\begin{array}{l}8 \\
0 \\
0 \\
1\end{array}$ & $\begin{array}{l}\text { Na } \\
\text { o- } \\
1\end{array}$ & $\stackrel{\bar{m}}{\bar{r}}$ & 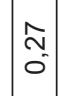 & $\begin{array}{l}0 \\
0 \\
0 \\
0 \\
1\end{array}$ & $\begin{array}{l}1 \\
0 \\
0 \\
1\end{array}$ & & $\stackrel{N}{\sim}$ & $\mid$ & $\begin{array}{l}1 \\
0 \\
0 \\
0\end{array}$ & $\frac{7}{5}$ & 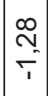 & $\frac{9}{5}$ & $\mid \begin{array}{l}0 \\
m \\
0 \\
0\end{array}$ & $\frac{\mathfrak{m}}{\stackrel{5}{\leftarrow}}$ & . \\
\hline ํㅡㅇ & $\mp$ & $\left|\begin{array}{c}4 \\
5 \\
\frac{5}{1}\end{array}\right|$ & 웅 & $\begin{array}{l}8 \\
\frac{-}{1}\end{array}$ & $\begin{array}{c}\bar{N} \\
\overline{0} \\
1\end{array}$ & "̂. & $\begin{array}{l} \pm \\
\\
i \\
i\end{array}$ & 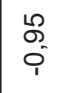 & $\begin{array}{l}5 \\
0 \\
0 \\
1\end{array}$ & & $F$ & 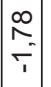 & 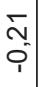 & $\begin{array}{l}\mathscr{N} \\
\stackrel{1}{1} \\
0\end{array}$ & 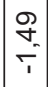 & Ñ & ָ̃ & $\frac{\hat{0}}{\leftarrow}$ & $\begin{array}{l}\text { J } \\
\text { O } \\
\text { i }\end{array}$ \\
\hline 훈 훙 & 우 & 0 & $\mid \begin{array}{l}0 \\
0 \\
0 \\
i\end{array}$ & $\begin{array}{l}0 \\
0 \\
0\end{array}$ & 离 & $\stackrel{\text { N }}{\circ}$ & $\begin{array}{l}\tilde{J} \\
m \\
0\end{array}$ & $\begin{array}{l}\infty \\
m \\
0 \\
0\end{array}$ & E. & & 응 & $\left|\begin{array}{c}1 \\
m \\
0\end{array}\right|$ & 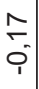 & $\begin{array}{l}\text { O } \\
0 \\
0\end{array}$ & $\begin{array}{l}1 \\
0 \\
0 \\
0 \\
1\end{array}$ & 욤 & 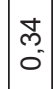 & $\begin{array}{l}\stackrel{8}{0} \\
0 \\
0\end{array}$ & $\stackrel{m}{\sigma}$ \\
\hline$\frac{0}{0}$ & a) & 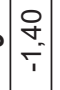 & 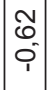 & $\begin{array}{l}\overline{0} \\
0 \\
\\
1\end{array}$ & $\begin{array}{l}\text { N } \\
0 \\
1\end{array}$ & $\begin{array}{l}\text { 苟 } \\
0 \\
0\end{array}$ & $\begin{array}{l}J_{0} \\
\sigma_{-}^{\prime}\end{array}$ & $\begin{array}{l}\hat{n} \\
0 \\
0\end{array}$ & $\underset{1}{\infty}$ & & a & $\left|\begin{array}{l}0 \\
\stackrel{m}{-} \\
\end{array}\right|$ & 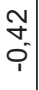 & $\frac{\infty}{\leftarrow}$ & $\begin{array}{l}0 \\
0 \\
0 \\
0 \\
1\end{array}$ & $\begin{array}{l}\infty \\
\infty \\
0 \\
1\end{array}$ & 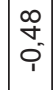 & $\stackrel{\bar{m}}{\leftarrow}$ & $\frac{\infty}{0_{1}^{\prime}}$ \\
\hline 8 & $\overline{\bar{J}} \mid \infty$ & $\left|\begin{array}{c}1 \\
N \\
N\end{array}\right|$ & 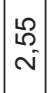 & $\mid \begin{array}{c}\infty \\
0 \\
\stackrel{\rho}{-} \\
-\end{array}$ & $\stackrel{\text { N }}{\stackrel{-}{0}}$ & $\stackrel{6}{=}$ & $\stackrel{0}{r}$ & $\stackrel{m}{i}$ & $\frac{9}{5}$ & 总 & $\infty$ & $\begin{array}{l}\text { D } \\
\text { O } \\
0\end{array}$ & $\begin{array}{l}\delta \\
\sigma\end{array}$ & Ñ & $\begin{array}{l}N \\
\sigma \\
0\end{array}$ & $\stackrel{\bar{m}}{\sim}$ & $\begin{array}{l}8 \\
0 \\
m\end{array}$ & $\begin{array}{l}\bar{m} \\
0 \\
\end{array}$ & $\begin{array}{l}0 \\
0 \\
0\end{array}$ \\
\hline$=$ & 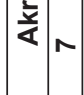 & $\left|\begin{array}{l}0 \\
0 \\
0 \\
0 \\
1\end{array}\right|$ & $\begin{array}{c}\bar{N} \\
\overline{0} \\
1\end{array}$ & $\mid \begin{array}{l}0 \\
0 \\
0 \\
1\end{array}$ & $\begin{array}{l}8 \\
6 \\
0 \\
1\end{array}$ & đ్ & $\begin{array}{l}0 \\
0 \\
0 \\
1\end{array}$ & $\begin{array}{l}\overline{6} \\
0 \\
1\end{array}$ & $\begin{array}{l}\bar{N} \\
0 \\
1\end{array}$ & $\frac{\bar{v}}{\frac{1}{\alpha}}$ & $N$ & $\mid$ & $\begin{array}{l}\infty \\
0 \\
0 \\
0\end{array}$ & $\begin{array}{l}8 \\
0 \\
1\end{array}$ & $\mid \begin{array}{l}\mathbf{N} \\
\mathbf{D} \\
0 \\
1\end{array}$ & 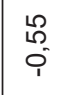 & $\mid \begin{array}{l}m \\
0 \\
0 \\
0 \\
1\end{array}$ & $\frac{\text { g }}{\leftarrow}$ & O̊ \\
\hline 'ब & • & $\left|\begin{array}{c}\overline{5} \\
0 \\
0 \\
1\end{array}\right|$ & 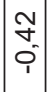 & $\begin{array}{l}4 \\
0 \\
0 \\
1\end{array}$ & $\begin{array}{l}\infty \\
10 \\
0 \\
1\end{array}$ & $\begin{array}{l}\text { Na } \\
\text { o } \\
1\end{array}$ & 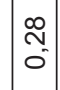 & o & $\begin{array}{l}\hat{m} \\
0 \\
0\end{array}$ & & 0 & $\mid$\begin{tabular}{l}
0 \\
0 \\
\hdashline \\
\hdashline-1
\end{tabular} & \begin{tabular}{l}
$\infty$ \\
\multirow{+}{*}{} \\
$\vdots$ \\
1
\end{tabular} & $\begin{array}{l}\text { \& } \\
0 \\
0 \\
\end{array}$ & 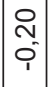 & 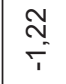 & $\begin{array}{l}2 \\
N \\
0 \\
1\end{array}$ & 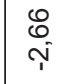 & 文 \\
\hline$\sqrt{\lambda}$ & n & $\mid \begin{array}{c}\tau \\
- \\
-\end{array}$ & $\frac{10}{5}$ & $\begin{array}{l}\hat{y} \\
0\end{array}$ & $\begin{array}{l}5 \\
0 \\
0 \\
1\end{array}$ & 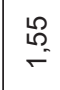 & $\begin{array}{l}0 \\
i \\
0 \\
1\end{array}$ & ه্ & $\begin{array}{l}3 \\
0 \\
0 \\
1\end{array}$ & & 10 & $\mid$\begin{tabular}{l|}
$\infty$ \\
\\
0 \\
1 \\
1
\end{tabular} & $\begin{array}{l}\hat{A} \\
0^{\prime}\end{array}$ & $\stackrel{\infty}{\infty}$ & \begin{tabular}{l}
$\mathscr{g}$ \\
\multirow{+}{*}{} \\
0
\end{tabular} & o̊ & $\begin{array}{l}E \\
\\
0 \\
1\end{array}$ & $\stackrel{\text { m}}{=}$ & $\begin{array}{l}8 \\
0 \\
0\end{array}$ \\
\hline o. & $\nabla$ & $\left|\begin{array}{l}0 \\
0 \\
0 \\
1\end{array}\right|$ & $\mid \begin{array}{l}0 \\
1 \\
0 \\
0 \\
1\end{array}$ & $\begin{array}{l}\infty \\
\\
0^{-1}\end{array}$ & $\frac{8}{5}$ & $\stackrel{\text { ๙ু }}{=}$ & $\begin{array}{l}0 \\
\Xi \\
0 \\
0\end{array}$ & $\stackrel{\infty}{\leftarrow}$ & $\begin{array}{l} \pm \\
\vdots \\
i \\
\end{array}$ & & $\nabla$ & $\begin{array}{c}8 \\
\\
\\
\\
1\end{array}$ & $\begin{array}{l}\text { พิ } \\
\stackrel{5}{0}\end{array}$ & $\begin{array}{l}0 \\
8 \\
0\end{array}$ & 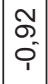 & $\begin{array}{l}\infty \\
\stackrel{0}{0} \\
0\end{array}$ & 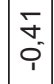 & $\stackrel{N}{\sim}$ & $\begin{array}{l}0 \\
10 \\
0 \\
0\end{array}$ \\
\hline$\frac{\pi}{2}$ & $m$ & 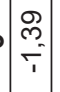 & $\begin{array}{l}1 \\
0 \\
0 \\
\end{array}$ & $\mid$\begin{tabular}{c|}
$\infty$ \\
$\infty$ \\
$\sim$ \\
1
\end{tabular} & $\underset{\mathscr{m}}{+}$ & $\begin{array}{l}\text { o. } \\
\text { ल }\end{array}$ & $\begin{array}{l}N^{\prime} \\
0^{\prime}\end{array}$ & $\frac{N}{\sigma}$ & $\frac{10}{2}$ & & $m$ & $\hat{f}_{-}$ & $\begin{array}{l}J_{-} \\
0^{\prime}\end{array}$ & $\stackrel{\infty}{\check{\sim}}$ & 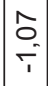 & 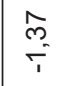 & $\begin{array}{l}1 \\
0 \\
0 \\
0\end{array}$ & $\begin{array}{l}\text { 응 } \\
\text { O. }\end{array}$ & 음 \\
\hline c & $N$ & $\left|\begin{array}{l}\infty \\
\infty \\
0 \\
1\end{array}\right|$ & $\mid \begin{array}{c}\hat{f} \\
0 \\
0 \\
1\end{array}$ & $\mid \begin{array}{l}0 \\
0 \\
0 \\
1\end{array}$ & $\frac{\widetilde{N}}{\leftarrow}$ & $\underset{r}{\sigma_{-}}$ & 垈 & $\begin{array}{l}\mathbb{N} \\
0^{-}\end{array}$ & 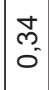 & & $\sim$ & $\mid$\begin{tabular}{c}
$\infty$ \\
$\stackrel{\infty}{N}$ \\
\hdashline 1
\end{tabular} & $\begin{array}{l}8 \\
0 \\
0 \\
1\end{array}$ & $\begin{array}{l}\ell \\
0 \\
0 \\
1\end{array}$ & $\begin{array}{l}0 \\
0 \\
0\end{array}$ & $\begin{array}{l}\bar{\infty} \\
0 \\
0\end{array}$ & - & $\begin{array}{l}8 \\
0 \\
0\end{array}$ & $\begin{array}{l}\infty \\
\infty \\
0 \\
0\end{array}$ \\
\hline$\tilde{J}$ & 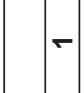 & $\mid \begin{array}{l}0 \\
0 \\
0 \\
1 \\
1\end{array}$ & $\mid \begin{array}{l}1 \\
0 \\
0 \\
1\end{array}$ & $\mid \begin{array}{l}0 \\
\infty \\
0 \\
0 \\
1\end{array}$ & $\frac{\infty}{0}$ & $\begin{array}{l}\text { Oo } \\
\text { Ni }\end{array}$ & $\begin{array}{l}8 \\
0 \\
0\end{array}$ & $\begin{array}{l}\text { o } \\
\text { ó }\end{array}$ & 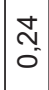 & & - & $\mid$\begin{tabular}{l}
$\Omega$ \\
\hdashline \\
\hdashline \\
\end{tabular} & 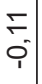 & $\frac{0}{5}$ & 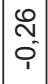 & $\begin{array}{l}\mathscr{L} \\
0 \\
0\end{array}$ & O̊ & $\begin{array}{l}\text { O̊ } \\
0 \\
1\end{array}$ & 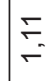 \\
\hline . & 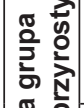 & 5 & ขี & 5 & ข & 5 & 강 & 5 & $\frac{v}{0}$ & 일 & & 당 & กิ & $\check{0}$ & กิ & 5 & 잉 & $\check{0}$ & กิ \\
\hline S. & 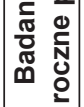 & $\bar{U}$ & $\frac{\vec{\sigma}}{\tilde{T}}$ & & & $\tilde{U}$ & & J & & 疍 & & 定 & & 宅 & $\underline{\widetilde{\sigma}}$ & 虽 & 茜 & 昰 & \\
\hline
\end{tabular}


W celu porównania dynamiki rozwojowej różnych cech pomiędzy zespołami

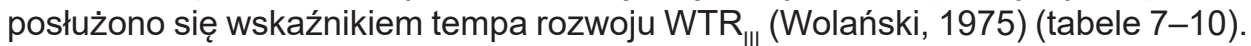
Analiza wykazała w większości cech zbliżone tempo rozwoju obu porównywanych zespołów - dzieci uprawiających akrobatykę sportową i dzieci z klas kontrolnych. Zaznacza się delikatna tendencja do wyższego tempa rozwoju u dzieci uprawiających akrobatykę sportową oraz do średnio większych przyrostów niektórych badanych cech u młodych adeptów akrobatyki sportowej, zwłaszcza w starszych grupach wieku. Zdecydowanie największe tempo rozwoju odnotowano w przyrostach masy ciała u wszystkich badanych dzieci.

Tabela 7. Zestawienie średnich wielkości wskaźników $\mathrm{WTR}_{\mathrm{II}}$ dla cech somatycznych u chłopców uprawiających akrobatykę sportową w poszczególnych grupach i seriach badań

\begin{tabular}{|c|c|c|c|c|c|c|c|c|}
\hline \multirow{4}{*}{$\begin{array}{c}\text { Cecha } \\
\text { somatyczna }\end{array}$} & \multicolumn{8}{|c|}{ Akrobaci } \\
\hline & \multicolumn{2}{|c|}{$A C 1$} & \multicolumn{2}{|c|}{ AC2 } & \multicolumn{2}{|c|}{ AC3 } & \multicolumn{2}{|c|}{$\mathrm{AC} 4$} \\
\hline & $\mathrm{WTR}_{\mathrm{III}} 1$ & $\mathrm{WTR}_{\mathrm{III}} 2$ & $\mathrm{WTR}_{\mathrm{III}} 1$ & $\mathrm{WTR}_{\mathrm{III}} 2$ & $\mathrm{WTR}_{\mathrm{III}} 1$ & $\mathrm{WTR}_{\mathrm{III}} 2$ & $\mathrm{WTR}_{\mathrm{III}} 1$ & $\mathrm{WTR}_{\mathrm{III}} 2$ \\
\hline & $10-9$ & $11-10$ & 11-10- & $12-11$ & $12-11$ & $13-12$ & $13-12$ & $14-13$ \\
\hline Wysokość ciała & 3,40 & 3,06 & 3,27 & 2,89 & 3,56 & 4,27 & 3,32 & 4,50 \\
\hline $\begin{array}{l}\text { Długość kończy- } \\
\text { ny dolnej }\end{array}$ & 4,19 & 4,22 & 4,25 & 4,24 & 4,52 & 5,41 & 4,46 & 4,48 \\
\hline Długość tułowia & 3,06 & 2,71 & 2,45 & 1,52 & 2,87 & 2,53 & 1,93 & 3,80 \\
\hline $\begin{array}{l}\text { Długość kończy- } \\
\text { ny górnej }\end{array}$ & 3,52 & 2,10 & 5,07 & 1,43 & 7,12 & 3,60 & 6,09 & 4,34 \\
\hline $\begin{array}{l}\text { Szerokość } \\
\text { barków }\end{array}$ & 4,46 & 2,46 & 4,55 & 3,05 & 4,30 & 2,80 & 5,80 & 3,70 \\
\hline $\begin{array}{l}\text { Szerokość klatki } \\
\text { piersiowej }\end{array}$ & 2,88 & 3,86 & 4,44 & 3,29 & 3,48 & 4,29 & 3,13 & 6,42 \\
\hline $\begin{array}{l}\text { Głębokość klatki } \\
\text { piersiowej }\end{array}$ & 2,89 & 4,48 & 4,03 & 4,28 & 6,11 & 3,43 & 4,07 & 5,56 \\
\hline $\begin{array}{l}\text { Szerokość } \\
\text { bioder }\end{array}$ & 0,52 & 7,62 & 5,89 & 7,40 & 6,87 & 7,56 & 1,78 & 6,01 \\
\hline Obwód brzucha & 2,38 & 2,71 & 4,35 & 3,56 & 2,46 & 6,06 & 3,72 & 4,42 \\
\hline Obwód bioder & 4,53 & 3,93 & 4,38 & 4,17 & 4,57 & 5,91 & 5,65 & 5,37 \\
\hline Obwód ramienia & 0,03 & 4,71 & 2,61 & 3,17 & 2,73 & 3,04 & 1,25 & 2,79 \\
\hline Obwód uda & $-0,35$ & 3,20 & 4,26 & 1,91 & 1,05 & 4,46 & 2,57 & 1,45 \\
\hline $\begin{array}{l}\text { Suma fałdów } \\
\text { tłuszczowych }\end{array}$ & 9,25 & $-3,44$ & 10,56 & $-7,11$ & 4,40 & 0,72 & 4,91 & $-1,09$ \\
\hline Masa ciała & 9,70 & 10,63 & 11,30 & 8,76 & 10,87 & 13,77 & 11,04 & 10,76 \\
\hline
\end{tabular}

Źródło: badania własne. 
Tabela 8. Zestawienie średnich wielkości wskaźników WTR ${ }_{\text {III }}$ dla cech somatycznych u dziewcząt uprawiających akrobatykę sportową w poszczególnych grupach i seriach badań

\begin{tabular}{|c|c|c|c|c|c|c|c|c|}
\hline \multirow{4}{*}{$\begin{array}{c}\text { Cecha } \\
\text { somatyczna }\end{array}$} & \multicolumn{8}{|c|}{ Akrobatki } \\
\hline & \multicolumn{2}{|c|}{ AD1 } & \multicolumn{2}{|c|}{ AD2 } & \multicolumn{2}{|c|}{ AD3 } & \multicolumn{2}{|c|}{ AD4 } \\
\hline & WTR $_{\text {III }} 1$ & WTR $_{\mathrm{III}} 2$ & $\mathrm{WTR}_{\mathrm{III}} 1$ & $\mathrm{WTR}_{\mathrm{III}} 2$ & WTR $_{\text {III }} 1$ & $\mathrm{WTR}_{\mathrm{III}} 2$ & $\mathrm{WTR}_{\mathrm{III}} 1$ & $\mathrm{WTR}_{\mathrm{III}} 2$ \\
\hline & $10-9$ & $11-10$ & $11-10-$ & $12-11$ & $12-11$ & $13-12$ & $13-12$ & $14-13$ \\
\hline Wysokość ciała & 3,03 & 3,63 & 3,69 & 3,64 & 3,87 & 3,55 & 3,06 & 2,42 \\
\hline $\begin{array}{l}\text { Długość kończy- } \\
\text { ny dolnej }\end{array}$ & 4,00 & 4,79 & 4,76 & 4,65 & 4,98 & 3,49 & 3,37 & 2,27 \\
\hline Długość tułowia & 2,68 & 3,29 & 3,48 & 2,46 & 2,13 & 3,65 & 2,82 & 2,70 \\
\hline $\begin{array}{l}\text { Długość kończy- } \\
\text { ny górnej }\end{array}$ & 2,37 & 4,70 & 4,86 & 2,28 & 5,63 & 3,16 & 5,63 & 3,50 \\
\hline $\begin{array}{l}\text { Szerokość } \\
\text { barków }\end{array}$ & 2,36 & 5,30 & 6,80 & 3,32 & 5,99 & 2,72 & 4,33 & 4,07 \\
\hline $\begin{array}{l}\text { Szerokość klatki } \\
\text { piersiowej }\end{array}$ & 1,41 & 4,31 & 3,18 & 5,11 & 1,95 & 5,55 & 0,40 & 3,04 \\
\hline $\begin{array}{l}\text { Głębokość klatki } \\
\text { piersiowej }\end{array}$ & 2,09 & 6,48 & 6,47 & 4,77 & 3,36 & 2,90 & 2,76 & 5,37 \\
\hline $\begin{array}{l}\text { Szerokość } \\
\text { bioder }\end{array}$ & 7,46 & 12,07 & 5,60 & 7,51 & 7,23 & 8,20 & 2,81 & 7,32 \\
\hline Obwód brzucha & 1,13 & 2,65 & $-0,09$ & 4,02 & 1,41 & 1,36 & 0,92 & 2,44 \\
\hline Obwód bioder & 4,14 & 4,20 & 4,52 & 4,48 & 6,85 & 6,12 & 4,29 & 6,87 \\
\hline Obwód ramienia & $-0,39$ & 2,79 & 4,01 & $-0,22$ & 3,10 & 4,59 & 0,55 & 4,59 \\
\hline Obwód uda & 2,90 & 4,67 & 1,27 & 2,29 & 3,96 & 5,27 & 1,63 & 6,15 \\
\hline $\begin{array}{l}\text { Suma fałdów } \\
\text { tłuszczowych }\end{array}$ & 4,31 & $-2,44$ & 4,62 & $-1,80$ & 5,51 & 0,59 & 6,17 & 3,38 \\
\hline Masa ciała & 12,50 & 10,71 & 10,67 & 9,82 & 10,95 & 13,82 & 9,32 & 13,53 \\
\hline
\end{tabular}

Źródło: badania własne.

Tabela 9. Zestawienie średnich wielkości wskaźników WTR $\mathrm{R}_{\text {III }}$ dla cech somatycznych u chłopców z klas kontrolnych w poszczególnych grupach i seriach badań

\begin{tabular}{|c|c|c|c|c|c|c|c|c|}
\hline \multirow{4}{*}{$\begin{array}{c}\text { Cecha } \\
\text { somatyczna }\end{array}$} & \multicolumn{8}{|c|}{ Chłopcy } \\
\hline & \multicolumn{2}{|c|}{ C1 } & \multicolumn{2}{|c|}{$\mathrm{C} 2$} & \multicolumn{2}{|c|}{ C3 } & \multicolumn{2}{|c|}{ C4 } \\
\hline & $\mathrm{WTR}_{\mathrm{III}} 1$ & $\mathrm{WTR}_{\mathrm{III}} 2$ & $\mathrm{WTR}_{\mathrm{II}} 1$ & WTR $_{\text {III }} 2$ & $\mathrm{WTR}_{\mathrm{III}} 1$ & WTR $_{\text {|II }} 2$ & WTR $_{\mathrm{III}} 1$ & $\mathrm{WTR}_{\mathrm{III}} 2$ \\
\hline & $10-9$ & $11-10$ & 11-10- & $12-11$ & $12-11$ & $13-12$ & $13-12$ & 14-13 \\
\hline Wysokość ciała & 3,71 & 3,44 & 3,71 & 3,81 & 1,88 & 3,39 & 2,79 & 4,00 \\
\hline $\begin{array}{l}\text { Długość kończy- } \\
\text { ny dolnej }\end{array}$ & 4,49 & 4,41 & 4,48 & 5,53 & 3,21 & 4,3 & 3,54 & 4,18 \\
\hline Długość tułowia & 3,71 & 2,74 & 4,41 & 1,00 & 0,48 & 1,61 & 1,77 & 3,94 \\
\hline $\begin{array}{l}\text { Długość kończy- } \\
\text { ny górnej }\end{array}$ & 3,90 & 3,17 & 3,58 & 3,90 & 3,54 & 2,54 & 3,30 & 4,56 \\
\hline $\begin{array}{l}\text { Szerokość } \\
\text { barków }\end{array}$ & 2,54 & 1,92 & 3,37 & 5,22 & 2,51 & 3,56 & 2,37 & 3,81 \\
\hline $\begin{array}{l}\text { Szerokość klatki } \\
\text { piersiowej }\end{array}$ & 4,312 & 5,16 & 4,35 & 5,01 & 3,84 & 3,47 & 3,94 & 3,95 \\
\hline $\begin{array}{l}\text { Głębokość klatki } \\
\text { piersiowej }\end{array}$ & 4,25 & 5,15 & 5,76 & 6,61 & 4,85 & 5,60 & 5,67 & 6,43 \\
\hline $\begin{array}{l}\text { Szerokość } \\
\text { bioder }\end{array}$ & 3,65 & 2,82 & 2,50 & 5,53 & 3,81 & 4,14 & 3,56 & 5,09 \\
\hline
\end{tabular}


Tabela 9. (cd.)

\begin{tabular}{|c|c|c|c|c|c|c|c|c|}
\hline \multirow{4}{*}{$\begin{array}{c}\text { Cecha } \\
\text { somatyczna }\end{array}$} & \multicolumn{8}{|c|}{ Chłopcy } \\
\hline & \multicolumn{2}{|c|}{ C1 } & \multicolumn{2}{|c|}{ C2 } & \multicolumn{2}{|c|}{ C3 } & \multicolumn{2}{|c|}{ C4 } \\
\hline & $\mathrm{WTR}_{\mathrm{III}} 1$ & $\mathrm{WTR}_{\mathrm{III}} 2$ & $\mathrm{WTR}_{\mathrm{III}} 1$ & WTR $_{\mathrm{III}} 2$ & $\mathrm{WTR}_{\mathrm{III}} 1$ & $W_{T R} 2$ & WTR $_{\text {III }} 1$ & WTR $_{\mathrm{III}} 2$ \\
\hline & $10-9$ & $11-10$ & $11-10-$ & $12-11$ & $12-11$ & $13-12$ & $13-12$ & $14-13$ \\
\hline Obwód brzucha & 5,66 & 5,15 & 4,47 & 4,56 & 4,16 & 3,74 & 4,76 & 4,70 \\
\hline Obwód bioder & 4,07 & 4,48 & 3,86 & 4,52 & 3,87 & 4,76 & 4,55 & 5,36 \\
\hline Obwód ramienia & 3,88 & 3,85 & 4,23 & 4,01 & 3,22 & 3,46 & 4,39 & 4,08 \\
\hline Obwód uda & 4,71 & 3,52 & 4,09 & 2,30 & 3,24 & 3,73 & 3,35 & 3,53 \\
\hline $\begin{array}{l}\text { Suma fałdów } \\
\text { tłuszczowych }\end{array}$ & 1,75 & $-0,20$ & 1,95 & 0,07 & 1,53 & 0,17 & 2,18 & $-1,04$ \\
\hline Masa ciała & 13,99 & 9,76 & 16,64 & 10,08 & 7,13 & 9,19 & 11,64 & 10,08 \\
\hline
\end{tabular}

Źródło: badania własne.

Tabela 10. Zestawienie średnich wielkości wskaźników WTR $_{\text {III }}$ dla cech somatycznych u dziewcząt z klas kontrolnych w poszczególnych grupach i seriach badań

\begin{tabular}{|c|c|c|c|c|c|c|c|c|}
\hline \multirow{4}{*}{$\begin{array}{c}\text { Cecha } \\
\text { somatyczna }\end{array}$} & \multicolumn{8}{|c|}{ Chłopcy } \\
\hline & \multicolumn{2}{|c|}{ C1 } & \multicolumn{2}{|c|}{$\mathrm{C} 2$} & \multicolumn{2}{|c|}{ C3 } & \multicolumn{2}{|c|}{ C4 } \\
\hline & $\mathrm{WTR}_{\mathrm{III}} 1$ & $\mathrm{WTR}_{\mathrm{III}} 2$ & WTR $_{\mathrm{III}} 1$ & $\mathrm{WTR}_{\mathrm{III}} 2$ & WTR $_{\mathrm{III}} 1$ & WTR $_{\mathrm{III}} 2$ & WTR $_{\mathrm{III}} 1$ & $\mathrm{WTR}_{\mathrm{III}} 2$ \\
\hline & $10-9$ & $11-10$ & $11-10-$ & $12-11$ & $12-11$ & $13-12$ & $13-12$ & 14-13 \\
\hline Wysokość ciała & 3,71 & 3,44 & 3,71 & 3,81 & 1,88 & 3,39 & 2,79 & 4,00 \\
\hline $\begin{array}{l}\text { Długość kończy- } \\
\text { ny dolnej }\end{array}$ & 4,49 & 4,41 & 4,48 & 5,53 & 3,21 & 4,3 & 3,54 & 4,18 \\
\hline Długość tułowia & 3,71 & 2,74 & 4,41 & 1,00 & 0,48 & 1,61 & 1,77 & 3,94 \\
\hline $\begin{array}{l}\text { Długość kończy- } \\
\text { ny górnej }\end{array}$ & 3,90 & 3,17 & 3,58 & 3,90 & 3,54 & 2,54 & 3,30 & 4,56 \\
\hline $\begin{array}{l}\text { Szerokość } \\
\text { barków }\end{array}$ & 2,54 & 1,92 & 3,37 & 5,22 & 2,51 & 3,56 & 2,37 & 3,81 \\
\hline $\begin{array}{l}\text { Szerokość klatki } \\
\text { piersiowej }\end{array}$ & 4,312 & 5,16 & 4,35 & 5,01 & 3,84 & 3,47 & 3,94 & 3,95 \\
\hline $\begin{array}{l}\text { Głębokość klatki } \\
\text { piersiowej }\end{array}$ & 4,25 & 5,15 & 5,76 & 6,61 & 4,85 & 5,60 & 5,67 & 6,43 \\
\hline $\begin{array}{l}\text { Szerokość } \\
\text { bioder }\end{array}$ & 3,65 & 2,82 & 2,50 & 5,53 & 3,81 & 4,14 & 3,56 & 5,09 \\
\hline Obwód brzucha & 5,66 & 5,15 & 4,47 & 4,56 & 4,16 & 3,74 & 4,76 & 4,70 \\
\hline Obwód bioder & 4,07 & 4,48 & 3,86 & 4,52 & 3,87 & 4,76 & 4,55 & 5,36 \\
\hline Obwód ramienia & 3,88 & 3,85 & 4,23 & 4,01 & 3,22 & 3,46 & 4,39 & 4,08 \\
\hline Obwód uda & 4,71 & 3,52 & 4,09 & 2,30 & 3,24 & 3,73 & 3,35 & 3,53 \\
\hline $\begin{array}{l}\text { Suma fałdów } \\
\text { tłuszczowych }\end{array}$ & 1,75 & $-0,20$ & 1,95 & 0,07 & 1,53 & 0,17 & 2,18 & $-1,04$ \\
\hline Masa ciała & 13,99 & 9,76 & 16,64 & 10,08 & 7,13 & 9,19 & 11,64 & 10,08 \\
\hline
\end{tabular}

Źródło: badania własne. 
Obecnie jawi się wyraźny obraz hipokinezy człowieka, powodowanej bardzo zróżnicowanymi czynnikami kulturowo-cywilizacyjnymi. Prowadzone w tym zakresie badania w Polsce i na świecie zmierzają w dwóch podstawowych kierunkach. Przy użyciu pierwszego z nich, zgodnie z koncepcją H-RF (health-related fitness), rozpatruje się sprawność motoryczną z punktu widzenia zdrowia, ograniczenia występowania chorób cywilizacyjnych, opóźnienia procesów inwolucyjnych, a także utrzymania możliwie jak najdłużej optymalnego poziomu sprawności fizycznej. Natomiast drugim kierunkiem naukowego zainteresowania są badania osiągnięć motorycznych związane ze sportem wysoko kwalifikowanym i jego wpływem na organizm człowieka (Osiński, 1998).

Oddziaływanie różnych form ćwiczeń fizycznych czy ogólnej ruchowej aktywności na organizm były przedmiotem różnych badań naukowych. Skutki tegoż działania mogą być szczególnie widoczne w przypadku młodego organizmu, znajdującego się jeszcze w okresie kształtowania podstawowych morfofunkcjonalnych struktur, cechujących się jeszcze znaczną plastycznością (Drozdowski, 2002). Wysiłek fizyczny wywołuje w organizmie różne zmiany, które zachodzą we wszystkich układach. Szczególna rola przypada jednak układowi mięśniowemu i kostnemu, które stanowią główny przedmiot zainteresowań antropologa.

Interpretację wyników dynamiki zmian badanych cech sprawności fizycznej z wiekiem przeprowadzono na podstawie bezwzględnych przeciętnych przyrostów rocznych cech (tabele 11-14), a także wielkości unormowanych (tabela 15).

Analiza ontogenetycznej zmienności badanych cech sprawności fizycznej wykazała, że dzieci uprawiające akrobatykę sportową, z wyjątkiem próby biegu wahadłowego $10 \times 5$ m, charakteryzują się w porównaniu ze swoimi rówieśnikami wyższym poziomem rozwoju motorycznego. Różnice w rozwoju pomiędzy porównywanymi zespołami z wiekiem w większości badanych cech i obu płci są nieco mniejsze. Przedmiotem rozważań w tym rozdziale stanie się zatem ocena dynamiki zmian cech sprawności fizycznej u dzieci uprawiających akrobatykę sportową w odniesieniu do dzieci nieuprawiających tej dyscypliny sportu.

Dynamika wzrastania poddanych analizie cech sprawności fizycznej kształtuje się w obu porównywanych zespołach, sportowym i kontrolnym, chłopców i dziewcząt, na zbliżonym poziomie. Jednakże z wiekiem zarysowuje się w większości badanych cech sprawności fizycznej tendencja do osiągania przez dzieci z klas kontrolnych średnio wyższych rocznych przyrostów. Zjawisko to najwyraźniej widoczne jest w próbie skłonu tułowia w przód z postawy i zwisie o ramionach ugiętych w nachwycie u dzieci obojga płci oraz wyskoku dosiężnego obunóż z miejsca w zespole męskim, zwłaszcza w najstarszej grupie i siadach z leżenia tyłem w zespole żeńskim.

W przypadku próby biegu wahadłowego 10 x $5 \mathrm{~m}$ z narastającą prędkością i zmianą kierunku ruchu, określonej czasem wykonania, obserwujemy nieco odmienny obraz. Analiza tej cechy wykazała u akrobatów i akrobatek niższy poziom rozwoju, jednakże z wiekiem, podobnie jak we wcześniej omawianych cechach, różnice międzyzespołowe są mniejsze. Tym razem jednak to dzieci uprawiające akrobatykę sportową uzyskiwały z wiekiem coraz większe średnie przyrosty tej cechy, dążąc do wyrównania poziomu w rozwoju zwinności i szybkości biegowej 
między porównywanymi zespołami, sportowym i kontrolnym, zarówno u dziewcząt jak i u chłopców.

Tabela 11. Ogólna charakterystyka statystyczna zmian (przyrostów) prób sprawności fizycznej u chłopców uprawiających akrobatykę sportową w poszczególnych grupach i seriach badań

\begin{tabular}{|c|c|c|c|c|c|c|c|c|c|}
\hline \multirow{3}{*}{\multicolumn{2}{|c|}{ Cechy somatyczne }} & \multicolumn{8}{|c|}{ Grupy akrobatów } \\
\hline & & \multicolumn{2}{|c|}{ AC1 } & \multicolumn{2}{|c|}{ AC2 } & \multicolumn{2}{|c|}{ AC3 } & \multicolumn{2}{|c|}{ AC4 } \\
\hline & & $10-9$ & $10-11$ & $10-11$ & $12-11$ & $12-11$ & $13-12$ & $13-12$ & $14-13$ \\
\hline $\begin{array}{l}\text { Skłon tułowia } \\
\text { w przód z po- } \\
\text { stawy }\end{array}$ & $\begin{array}{l}M \\
S_{d}\end{array}$ & $\begin{array}{l}1,92 \\
2,53\end{array}$ & $\begin{array}{l}0,38 \\
2,02\end{array}$ & $\begin{array}{l}0,71 \\
1,38\end{array}$ & $\begin{array}{l}1,00 \\
1,15\end{array}$ & $\begin{array}{l}0,77 \\
1,09\end{array}$ & $\begin{array}{c}-1,54 \\
1,33\end{array}$ & $\begin{array}{l}0,14 \\
3,08\end{array}$ & $\begin{array}{r}-0,57 \\
1,27\end{array}$ \\
\hline $\begin{array}{l}\text { Wyskok do- } \\
\text { siężny obunóż } \\
\text { z miejsca }\end{array}$ & $\begin{array}{l}M \\
S_{d}\end{array}$ & $\begin{array}{l}2,00 \\
2,04\end{array}$ & $\begin{array}{l}4,00 \\
3,27\end{array}$ & $\begin{array}{l}1,00 \\
4,51\end{array}$ & $\begin{array}{l}2,71 \\
3,55\end{array}$ & $\begin{array}{l}0,77 \\
4,38\end{array}$ & $\begin{array}{l}3,92 \\
3,82\end{array}$ & $\begin{array}{l}1,14 \\
3,39\end{array}$ & $\begin{array}{l}0,29 \\
2,21\end{array}$ \\
\hline $\begin{array}{l}\text { Skok w dal obu- } \\
\text { nóż z miejsca }\end{array}$ & $\begin{array}{l}M \\
S_{d}\end{array}$ & $\begin{array}{l}7,69 \\
8,22 \\
\end{array}$ & $\begin{array}{c}8,00 \\
15,23 \\
\end{array}$ & $\begin{array}{c}4,14 \\
14,76 \\
\end{array}$ & $\begin{array}{c}10,86 \\
9,82 \\
\end{array}$ & $\begin{array}{l}15,23 \\
8,45 \\
\end{array}$ & $\begin{array}{l}15,23 \\
8,45 \\
\end{array}$ & $\begin{array}{c}6,29 \\
11,67 \\
\end{array}$ & $\begin{array}{l}10,71 \\
18,27 \\
\end{array}$ \\
\hline $\begin{array}{l}\text { Zwis na drążku } \\
\text { o rr. ugiętych }\end{array}$ & $\begin{array}{l}\text { M } \\
S_{d}\end{array}$ & $\begin{array}{l}5,21 \\
5,11\end{array}$ & $\begin{array}{c}7,76 \\
11,32\end{array}$ & $\begin{array}{l}4,93 \\
8,41\end{array}$ & $\begin{array}{l}-7,82 \\
15,75\end{array}$ & $\begin{array}{c}0,21 \\
15,69\end{array}$ & $\begin{array}{c}-4,02 \\
9,74\end{array}$ & $\begin{array}{l}-7,39 \\
10,69\end{array}$ & $\begin{array}{c}-5,44 \\
8,23\end{array}$ \\
\hline $\begin{array}{l}\text { Siady z leżenia } \\
\text { tyłem }\end{array}$ & $\begin{array}{l}M \\
S_{d}\end{array}$ & $\begin{array}{l}3,00 \\
2,12 \\
\end{array}$ & $\begin{array}{l}2,46 \\
2,44\end{array}$ & $\begin{array}{l}2,29 \\
2,21\end{array}$ & $\begin{array}{l}1,29 \\
2,14\end{array}$ & $\begin{array}{l}2,00 \\
1,68\end{array}$ & $\begin{array}{l}0,38 \\
1,45 \\
\end{array}$ & $\begin{array}{l}0,14 \\
3,34\end{array}$ & $\begin{array}{l}0,43 \\
2,07\end{array}$ \\
\hline $\begin{array}{l}\text { Bieg wahadłowy } \\
10 \times 5 \mathrm{~m}\end{array}$ & $\begin{array}{l}M \\
S_{d}\end{array}$ & $\begin{array}{c}-0,09 \\
1,11 \\
\end{array}$ & $\begin{array}{c}-0,44 \\
1,62\end{array}$ & $\begin{array}{l}0,39 \\
1,30\end{array}$ & $\begin{array}{l}0,50 \\
1,34\end{array}$ & $\begin{array}{l}0,09 \\
1,55\end{array}$ & $\begin{array}{c}-0,29 \\
2,13\end{array}$ & $\begin{array}{l}0,09 \\
0,52\end{array}$ & $\begin{array}{l}1,11 \\
1,65\end{array}$ \\
\hline
\end{tabular}

Źródło: badania własne.

Tabela 12. Ogólna charakterystyka statystyczna zmian (przyrostów) prób sprawności fizycznej u chłopców z klas kontrolnych w poszczególnych grupach i seriach badań

\begin{tabular}{|c|c|c|c|c|c|c|c|c|c|}
\hline \multirow{3}{*}{\multicolumn{2}{|c|}{ Cechy somatyczne }} & \multicolumn{8}{|c|}{ Grupy chłopców } \\
\hline & & \multicolumn{2}{|c|}{ C1 } & \multicolumn{2}{|c|}{ C2 } & \multicolumn{2}{|c|}{ C3 } & \multicolumn{2}{|c|}{ C4 } \\
\hline & & $10-9$ & 10-11 & $10-11$ & $12-11$ & $12-11$ & $13-12$ & 13-12 & $14-13$ \\
\hline $\begin{array}{l}\text { Skłon tułowia } \\
\text { w przód z po- } \\
\text { stawy }\end{array}$ & $\begin{array}{l}M \\
S_{d}\end{array}$ & $\begin{array}{r}-0,07 \\
2,63\end{array}$ & $\begin{array}{l}0,48 \\
3,37\end{array}$ & $\begin{array}{l}1,68 \\
5,52\end{array}$ & $\begin{array}{l}-0,74 \\
2,64\end{array}$ & $\begin{array}{l}2,47 \\
3,82\end{array}$ & $\begin{array}{l}0,53 \\
2,61\end{array}$ & $\begin{array}{l}3,00 \\
4,16\end{array}$ & $\begin{array}{l}1,27 \\
4,34\end{array}$ \\
\hline $\begin{array}{l}\text { Wyskok do- } \\
\text { siężny obunóż } \\
\text { z miejsca }\end{array}$ & $\begin{array}{l}M \\
S_{d}\end{array}$ & $\begin{array}{l}0,30 \\
2,37\end{array}$ & $\begin{array}{l}3,63 \\
3,79\end{array}$ & $\begin{array}{l}2,68 \\
5,33\end{array}$ & $\begin{array}{l}3,00 \\
3,32\end{array}$ & $\begin{array}{l}2,16 \\
3,88\end{array}$ & $\begin{array}{l}3,58 \\
3,64\end{array}$ & $\begin{array}{l}3,45 \\
4,25\end{array}$ & $\begin{array}{l}5,59 \\
4,47\end{array}$ \\
\hline $\begin{array}{l}\text { Skok w dal obu- } \\
\text { nóż z miejsca }\end{array}$ & \begin{tabular}{|l|}
$M$ \\
$S_{d}$ \\
\end{tabular} & $\begin{array}{c}4,81 \\
10,36 \\
\end{array}$ & \begin{tabular}{c|}
7,78 \\
11,12 \\
\end{tabular} & $\begin{array}{c}2,79 \\
14,63 \\
\end{array}$ & $\begin{array}{c}14,00 \\
9,17 \\
\end{array}$ & $\begin{array}{l}2,58 \\
6,13 \\
\end{array}$ & $\begin{array}{l}12,26 \\
12,49 \\
\end{array}$ & $\begin{array}{c}6,95 \\
10,90 \\
\end{array}$ & $\begin{array}{l}15,23 \\
10,61 \\
\end{array}$ \\
\hline $\begin{array}{l}\text { Zwis na drążku } \\
\text { o rr. ugiętych }\end{array}$ & \begin{tabular}{|l|}
$M$ \\
$S_{d}$ \\
\end{tabular} & $\begin{array}{l}4,22 \\
8,25 \\
\end{array}$ & $\begin{array}{l}-2,17 \\
9,54 \\
\end{array}$ & $\begin{array}{l}-0,05 \\
15,73 \\
\end{array}$ & $\begin{array}{l}0,25 \\
7,67 \\
\end{array}$ & $\begin{array}{l}-2,35 \\
5,99 \\
\end{array}$ & $\begin{array}{c}3,60 \\
13,11 \\
\end{array}$ & $\begin{array}{l}1,73 \\
5,09 \\
\end{array}$ & $\begin{array}{l}6,17 \\
8,84 \\
\end{array}$ \\
\hline $\begin{array}{l}\text { Siady z leżenia } \\
\text { tyłem }\end{array}$ & \begin{tabular}{|l|}
$M$ \\
$S_{d}$ \\
\end{tabular} & $\begin{array}{l}0,78 \\
3,57 \\
\end{array}$ & $\begin{array}{l}3,96 \\
4,37 \\
\end{array}$ & $\begin{array}{l}0,84 \\
3,44 \\
\end{array}$ & $\begin{array}{l}1,26 \\
3,03 \\
\end{array}$ & $\begin{array}{l}0,89 \\
4,32 \\
\end{array}$ & $\begin{array}{r}-0,11 \\
4,88 \\
\end{array}$ & $\begin{array}{l}0,68 \\
2,71\end{array}$ & $\begin{array}{l}1,86 \\
2,27 \\
\end{array}$ \\
\hline $\begin{array}{l}\text { Bieg wahadłowy } \\
10 \times 5 \mathrm{~m}\end{array}$ & $\begin{array}{l}M \\
S_{d}\end{array}$ & $\begin{array}{c}-0,21 \\
1,99 \\
\end{array}$ & $\begin{array}{r}-1,28 \\
1,76 \\
\end{array}$ & $\begin{array}{c}-0,98 \\
5,01 \\
\end{array}$ & $\begin{array}{l}-0,23 \\
5,65\end{array}$ & $\begin{array}{l}0,63 \\
1,28\end{array}$ & $\begin{array}{r}-1,10 \\
1,40 \\
\end{array}$ & $\begin{array}{l}0,39 \\
1,23\end{array}$ & $\begin{array}{r}-1,58 \\
1,04 \\
\end{array}$ \\
\hline
\end{tabular}

Źródło: badania własne. 
Tabela 13. Ogólna charakterystyka statystyczna zmian (przyrostów) prób sprawności fizycznej u dziewcząt uprawiających akrobatykę sportową w poszczególnych grupach i seriach badań

\begin{tabular}{|c|c|c|c|c|c|c|c|c|c|}
\hline \multirow{3}{*}{\multicolumn{2}{|c|}{ Cechy somatyczne }} & \multicolumn{8}{|c|}{ Grupy akrobatek } \\
\hline & & \multicolumn{2}{|c|}{ AD1 } & \multicolumn{2}{|c|}{ AD2 } & \multicolumn{2}{|c|}{ AD3 } & \multicolumn{2}{|c|}{ AD4 } \\
\hline & & $10-9$ & $10-11$ & $10-11$ & $12-11$ & 12-11 & $13-12$ & $13-12$ & 14-13 \\
\hline $\begin{array}{l}\text { Skłon tułowia } \\
\text { w przód z po- } \\
\text { stawy }\end{array}$ & $\begin{array}{l}M \\
S_{d}\end{array}$ & $\begin{array}{l}1,67 \\
2,45\end{array}$ & $\begin{array}{l}0,89 \\
1,54\end{array}$ & $\begin{array}{l}0,82 \\
1,72\end{array}$ & $\begin{array}{l}0,36 \\
1,36\end{array}$ & $\begin{array}{l}1,44 \\
4,53\end{array}$ & $\begin{array}{c}-0,33 \\
2,87\end{array}$ & $\begin{array}{l}0,50 \\
2,07\end{array}$ & $\begin{array}{c}-0,25 \\
2,43\end{array}$ \\
\hline $\begin{array}{l}\text { Wyskok do- } \\
\text { siężny obunóż } \\
\text { z miejsca }\end{array}$ & $\begin{array}{l}M \\
S_{d}\end{array}$ & $\begin{array}{l}4,11 \\
1,96\end{array}$ & $\begin{array}{l}4,89 \\
3,55\end{array}$ & $\begin{array}{l}0,91 \\
4,59\end{array}$ & $\begin{array}{l}2,09 \\
4,48\end{array}$ & $\begin{array}{l}3,33 \\
3,39\end{array}$ & $\begin{array}{l}1,56 \\
2,74\end{array}$ & $\begin{array}{l}1,63 \\
2,97\end{array}$ & $\begin{array}{l}1,00 \\
2,00\end{array}$ \\
\hline $\begin{array}{l}\text { Skok w dal obu- } \\
\text { nóż z miejsca }\end{array}$ & $\begin{array}{l}M \\
S_{d}\end{array}$ & $\begin{array}{c}8,44 \\
15,34 \\
\end{array}$ & $\begin{array}{l}12,33 \\
12,60 \\
\end{array}$ & $\begin{array}{c}9,36 \\
11,53\end{array}$ & $\begin{array}{c}7,00 \\
11,37 \\
\end{array}$ & $\begin{array}{l}1,22 \\
4,21\end{array}$ & $\begin{array}{c}4,33 \\
12,24 \\
\end{array}$ & $\begin{array}{l}10,38 \\
17,94 \\
\end{array}$ & $\begin{array}{c}2,75 \\
12,57\end{array}$ \\
\hline $\begin{array}{l}\text { Zwis na drążku } \\
\text { o rr. ugiętych }\end{array}$ & $\begin{array}{l}M \\
S_{d} \\
\end{array}$ & $\begin{array}{l}2,01 \\
8,75 \\
\end{array}$ & $\begin{array}{l}5,35 \\
8,09 \\
\end{array}$ & $\begin{array}{l}2,52 \\
7,56 \\
\end{array}$ & $\begin{array}{c}-5,65 \\
6,71 \\
\end{array}$ & $\begin{array}{l}-2,51 \\
8,00 \\
\end{array}$ & $\begin{array}{c}-5,42 \\
4,93 \\
\end{array}$ & $\begin{array}{l}1,43 \\
6,43 \\
\end{array}$ & $\begin{array}{c}-4,08 \\
6,01 \\
\end{array}$ \\
\hline $\begin{array}{l}\text { Siady z leżenia } \\
\text { tyłem }\end{array}$ & $\begin{array}{l}M \\
S_{d}\end{array}$ & $\begin{array}{l}5,33 \\
3,91 \\
\end{array}$ & $\begin{array}{l}1,56 \\
1,88 \\
\end{array}$ & $\begin{array}{l}2,45 \\
1,69 \\
\end{array}$ & $\begin{array}{l}0,45 \\
1,51\end{array}$ & $\begin{array}{l}1,67 \\
2,87 \\
\end{array}$ & $\begin{array}{l}0,44 \\
3,32\end{array}$ & $\begin{array}{l}0,63 \\
2,45\end{array}$ & $\begin{array}{l}0,50 \\
1,31 \\
\end{array}$ \\
\hline $\begin{array}{l}\text { Bieg wahadłowy } \\
10 \times 5 \mathrm{~m}\end{array}$ & $\begin{array}{l}M \\
S_{d}\end{array}$ & $\begin{array}{r}-1,71 \\
1,42 \\
\end{array}$ & $\begin{array}{c}-1,10 \\
1,06 \\
\end{array}$ & $\begin{array}{c}-0,29 \\
1,05 \\
\end{array}$ & $\begin{array}{l}0,56 \\
1,31\end{array}$ & $\begin{array}{l}0,40 \\
0,76 \\
\end{array}$ & $\begin{array}{l}0,05 \\
0,71\end{array}$ & $\begin{array}{l}0,28 \\
1,72 \\
\end{array}$ & $\begin{array}{l}0,80 \\
0,67 \\
\end{array}$ \\
\hline
\end{tabular}

Źródło: badania własne.

Tabela 14. Ogólna charakterystyka statystyczna zmian (przyrostów) prób sprawności fizycznej u dziewcząt z klas kontrolnych w poszczególnych grupach i seriach badań

\begin{tabular}{|c|c|c|c|c|c|c|c|c|c|}
\hline \multirow{3}{*}{\multicolumn{2}{|c|}{ Cechy somatyczne }} & \multicolumn{8}{|c|}{ Grupy dziewcząt } \\
\hline & & \multicolumn{2}{|c|}{ D1 } & \multicolumn{2}{|c|}{ D2 } & \multicolumn{2}{|c|}{ D3 } & \multicolumn{2}{|c|}{ D4 } \\
\hline & & $10-9$ & $10-11$ & $10-11$ & $12-11$ & $12-11$ & $13-12$ & $13-12$ & 14-13 \\
\hline $\begin{array}{l}\text { Skłon tułowia } \\
\text { w przód z po- } \\
\text { stawy }\end{array}$ & $\begin{array}{l}M \\
S_{d}\end{array}$ & $\begin{array}{l}2,96 \\
4,05\end{array}$ & $\begin{array}{l}2,37 \\
4,68\end{array}$ & $\begin{array}{l}5,21 \\
4,39\end{array}$ & $\begin{array}{l}-0,21 \\
3,26\end{array}$ & $\begin{array}{l}5,35 \\
3,85\end{array}$ & $\begin{array}{l}0,73 \\
3,82\end{array}$ & $\begin{array}{l}3,57 \\
3,30\end{array}$ & $\begin{array}{l}1,38 \\
2,87\end{array}$ \\
\hline $\begin{array}{l}\text { Wyskok do- } \\
\text { siężny obunóż } \\
\text { z miejsca }\end{array}$ & $\begin{array}{l}M \\
S_{d}\end{array}$ & $\begin{array}{l}0,19 \\
3,40\end{array}$ & $\begin{array}{l}3,41 \\
3,03\end{array}$ & $\begin{array}{l}2,03 \\
3,82\end{array}$ & $\begin{array}{l}2,41 \\
3,90\end{array}$ & $\begin{array}{l}3,15 \\
4,15\end{array}$ & $\begin{array}{l}1,35 \\
3,41\end{array}$ & $\begin{array}{l}2,10 \\
3,79\end{array}$ & $\begin{array}{l}1,86 \\
3,57\end{array}$ \\
\hline $\begin{array}{l}\text { Skok w dal obu- } \\
\text { nóż z miejsca }\end{array}$ & $\begin{array}{l}M \\
S_{d}\end{array}$ & $\begin{array}{l}4,07 \\
10,50\end{array}$ & $\begin{array}{l}13,63 \\
10,78\end{array}$ & $\begin{array}{c}3,90 \\
10,46\end{array}$ & $\begin{array}{c}7,66 \\
10,40\end{array}$ & $\begin{array}{c}1,31 \\
24,19\end{array}$ & $\begin{array}{c}6,35 \\
11,20\end{array}$ & $\begin{array}{c}5,62 \\
11,09\end{array}$ & $\begin{array}{l}5,67 \\
11,05\end{array}$ \\
\hline $\begin{array}{l}\text { Zwis na drążku } \\
\text { o rr. ugiętych }\end{array}$ & $\begin{array}{l}M \\
S_{d}\end{array}$ & $\begin{array}{c}-0,15 \\
6,51 \\
\end{array}$ & $\begin{array}{l}0,37 \\
5,84\end{array}$ & $\begin{array}{l}0,54 \\
4,44\end{array}$ & $\begin{array}{c}-0,94 \\
4,17 \\
\end{array}$ & $\begin{array}{l}0,79 \\
1,14 \\
\end{array}$ & $\begin{array}{l}0,27 \\
4,70\end{array}$ & $\begin{array}{l}3,36 \\
9,93 \\
\end{array}$ & $\begin{array}{c}-0,60 \\
9,21\end{array}$ \\
\hline $\begin{array}{l}\text { Siady z leżenia } \\
\text { tyłem }\end{array}$ & $\begin{array}{l}M \\
S_{d}\end{array}$ & $\begin{array}{l}0,74 \\
2,23\end{array}$ & $\begin{array}{l}3,56 \\
3,49\end{array}$ & $\begin{array}{l}1,07 \\
3,18\end{array}$ & $\begin{array}{l}1,66 \\
3,88\end{array}$ & $\begin{array}{l}-0,46 \\
2,44\end{array}$ & $\begin{array}{l}1,81 \\
2,17\end{array}$ & $\begin{array}{l}0,62 \\
2,84\end{array}$ & $\begin{array}{l}1,81 \\
2,80\end{array}$ \\
\hline $\begin{array}{l}\text { Bieg wahadłowy } \\
10 \times 5 \mathrm{~m}\end{array}$ & $\begin{array}{l}M \\
S_{d}\end{array}$ & $\begin{array}{l}1,05 \\
1,50\end{array}$ & $\begin{array}{c}-1,54 \\
2,77\end{array}$ & $\begin{array}{l}0,74 \\
1,78\end{array}$ & $\begin{array}{c}-1,74 \\
2,79\end{array}$ & $\begin{array}{l}0,37 \\
0,83\end{array}$ & $\begin{array}{c}-0,79 \\
1,20\end{array}$ & $\begin{array}{r}-0,11 \\
1,66\end{array}$ & $\begin{array}{c}-0,32 \\
1,67\end{array}$ \\
\hline
\end{tabular}

Źródło: badania własne. 
Tabela 15. Zestawienie średnich wystandaryzowanych wielkości rocznych przyrostów cech sprawności fizycznej: 1. Skłon tułowia wprzód z postawy, 2. Wyskok dosiężny obunóż z miejsca, 3. Skok w dal z miejsca, 4. Zwis na drążku, 5. Siady skulone z leżenie tyłem, 6. Bieg wahadłowy $10 \times 5 \mathrm{~m}$

\begin{tabular}{|c|c|c|c|c|c|c|c|}
\hline \multirow{2}{*}{\multicolumn{2}{|c|}{$\begin{array}{l}\text { Badana grupa } \\
\text { i roczne przyrosty }\end{array}$}} & \multicolumn{6}{|c|}{ Akrobaci } \\
\hline & & 1 & 2 & 3 & 4 & 5 & 6 \\
\hline \multirow{2}{*}{$\begin{array}{l}\mathrm{AC1} \\
9-11 \text { lat }\end{array}$} & d1 & 0,76 & 0,72 & 0,28 & 0,12 & 0,62 & 0,06 \\
\hline & $\mathrm{d} 2$ & $-0,03$ & 0,10 & 0,02 & 1,04 & $-0,34$ & 0,48 \\
\hline \multirow{2}{*}{$\begin{array}{l}\mathrm{AC2} \\
10-12 \text { lat }\end{array}$} & d1 & $-0,18$ & $-0,32$ & 0,09 & 0,32 & 0,42 & 0,27 \\
\hline & $\mathrm{d} 2$ & 0,66 & 0,09 & $-0,34$ & $-1,05$ & 0,01 & 0,13 \\
\hline \multirow{2}{*}{$\begin{array}{l}\text { AC3 } \\
11-13 \text { lat }\end{array}$} & d1 & $-0,45$ & $-0,36$ & 2,06 & 0,43 & 0,26 & $-0,42$ \\
\hline & $\mathrm{d} 2$ & $-0,79$ & 0,09 & 0,24 & $-0,58$ & 0,10 & 0,58 \\
\hline \multirow{2}{*}{$\begin{array}{l}\text { AC4 } \\
12-14 \text { lat }\end{array}$} & d1 & $-0,69$ & $-0,54$ & $-0,06$ & $-1,79$ & $-0,20$ & $-0,24$ \\
\hline & $\mathrm{d} 2$ & $-0,42$ & $-1,19$ & $-0,43$ & $-1,31$ & $-0,63$ & 2,60 \\
\hline \multirow{2}{*}{\multicolumn{2}{|c|}{ Badana grupa i roczne przyrosty }} & \multicolumn{6}{|c|}{ Akrobatki } \\
\hline & & 1 & 2 & 3 & 4 & 5 & 6 \\
\hline \multirow{2}{*}{$\begin{array}{l}\text { AD1 } \\
\text { 9-11 lat }\end{array}$} & d1 & $-0,32$ & 1,16 & 0,42 & 0,33 & 2,06 & $-1,84$ \\
\hline & $\mathrm{d} 2$ & $-0,32$ & 0,49 & $-0,12$ & 0,85 & $-0,57$ & 0,16 \\
\hline \multirow{2}{*}{$\begin{array}{l}A D 2 \\
10-12 \text { lat }\end{array}$} & $\mathrm{d} 1$ & $-1,00$ & $-0,29$ & 0,52 & 0,45 & 0,44 & $-0,58$ \\
\hline & $\mathrm{d} 2$ & 0,18 & $-0,08$ & $-0,06$ & $-1,13$ & $-0,31$ & 0,82 \\
\hline \multirow{2}{*}{$\begin{array}{l}\text { AD3 } \\
11-13 \text { lat }\end{array}$} & d1 & $-1,01$ & 0,04 & 0 & 0,80 & 0,87 & 0,04 \\
\hline & $\mathrm{d} 2$ & $-0,28$ & 0,06 & $-0,18$ & $-1,21$ & $-0,63$ & 0,70 \\
\hline \multirow{2}{*}{$\begin{array}{l}\text { AD4 } \\
12-14 \text { lat }\end{array}$} & $\mathrm{d} 1$ & $-0,93$ & $-0,12$ & 0,43 & $-0,19$ & 0 & 0,24 \\
\hline & $\mathrm{d} 2$ & $-0,57$ & $-0,24$ & $-0,26$ & $-0,38$ & $-0,47$ & 0,67 \\
\hline
\end{tabular}

Źródło: badania własne.

\section{Podsumowanie i dyskusja}

Punktem wyjścia do dyskusji stał się pogląd, że aktywność ruchowa jako jeden z wielu środowiskowych czynników rozwoju może mieć znaczący wpływ na procesy rozwojowe organizmu. Jak podaje Z. Drozdowski (2002) „zmiany biologiczne zachodzące w organizmie dziecka, pod wpływem określonych form działania ruchowej aktywności są istotnie związane z wiekiem ich podejmowania - są tym większe, im wcześniej zaczyna się uprawiać określone ćwiczenia”.

Na podstawie dotychczasowych badań można stwierdzić, że odpowiednio dobrane ćwiczenia fizyczne o umiarkowanej intensywności mogą mieć korzystny wpływ na rozwój biologiczny i zdrowie dziecka (Dancewicz, 1999). Jednakże obok tych ogólnie uznawanych i przytaczanych korzystnych skutków zwiększonej aktywności ruchowej dziecka mogą jednak pojawić się efekty niekorzystne, szczególnie gdy obciążenia przekraczają fizjologicznie dopuszczalne granice, powodując np. zahamowanie wzrastania, zaburzenia proporcji budowy ciała, powstawanie wad postawy (Ziemilska, 1984).

W niniejszej pracy rozpatrywano kwestię związaną z wpływem systematycznych ćwiczeń fizycznych z zakresu akrobatyki sportowej na organizm młodych 
akrobatów i akrobatek. Wzrastanie i tempo rozwoju niemal wszystkich porównywanych cech budowy somatycznej młodych akrobatów i akrobatek było zbliżone, a czasem większe, niż średnie przyrosty tychże cech u dzieci grupy porównawczej. Obserwuje się w porównywanych grupach tendencję do wyrównywania z wiekiem poziomu rozwoju poszczególnych cech somatycznych, zwłaszcza długościowych. Można powiedzieć, że trening akrobatyczny na etapie szkolenia wstępnego i podstawowego stymuluje parametry rozwoju somatycznego. Mimo to przeciętny poziom rozwoju somatycznego, nadal jest niższy w klasach sportowych. Najprawdopodobniej czynnikiem wpływającym na odmienność procesów wzrastania w obu porównywanych grupach może być różny stopień zawansowania w dojrzewaniu płciowym i związane z tym różnice w rozmiarach ciała szczególnie w okresie pokwitania. Zatem większa dynamika wzrastania cech somatycznych u dzieci z klas akrobatycznych wynikać może z późniejszego dojrzewanie płciowego. Świadczyć to może również o braku negatywnego wpływu oddziaływania tego typu szkolenia sportowego na organizm młodych adeptów akrobatyki sportowej. Podobne efekty zaobserwowano w pracach innych autorów (Kochanowicz, 1998, Kruczkowski, 1998, Dancewicz, 1999).

Brak spostrzeżeń dotyczących negatywnego wpływu ćwiczeń fizycznych na organizm dziecka wynika z nieco odmiennego kierunku optymalizacji szkolenia sportowego akrobatycznego czy też gimnastycznego. Obecnie jest on ukierunkowany przede wszystkim na długotrwałe, czy też długoletnie uczestnictwo dzieci w sporcie.

Niektóre z cech, jak szerokość klatki piersiowej, głębokość klatki piersiowej czy też długość tułowia nie wykazują większych różnic między dziećmi z klas sportowych i ich rówieśnikami, charakteryzując się podobnym poziomem ontogenetycznego rozwoju tychże cech już w czasie pierwszego badania. Podobne spostrzeżenia odnaleźć możemy w pracy Dancewicza, dotyczącej chłopców uprawiających gimnastykę sportową. Stwierdził on, że parametr szerokościowy klatki piersiowej gimnastyków przyjmował niższe wartości w momencie rozpoczęcia treningów, by po upływie dwóch lat wyrównać się z wartościami porównywanej populacji. Wyższe natomiast wartości odnotowano dla długości tułowia i obwodu klatki piersiowej (Dancewicz, 1999). Niemalże identyczne spostrzeżenia mogą być wynikiem specyficznej budowy ciała typowej dla osób uprawniających akrobatykę jak i gimnastykę sportową. Budowa ta najogólniej charakteryzuje się wyraźnie zarysowanym umięśnieniem całego ciała, silnie rozwiniętym szkieletem a przede wszystkim przewagą rozwoju klatki piersiowej nad okolicą brzucha i bioder, dłuższym tułowiem oraz proporcjonalnie rozwiniętymi kończynami górnymi i dolnymi (Firak, 2003).

Rozwój poszczególnych zdolności motorycznych młodego organizmu w ontogenezie nie może być zasadą ogólnego i równomiernego kształtowania motoryczności, lecz celowym i wybiórczym stymulowaniem procesów rozwojowych z wykorzystaniem naturalnej fazowości i dynamiki rozwoju zdolności motorycznych. Postępowanie to wynika z faktu, że dynamika i tempo rozwoju poszczególnych zdolności motorycznych są zróżnicowane, nierównomierne i zindywidualizowane, osiągające swoje apogeum w innych okresach życia (Raczek, 1986). 
Najbardziej skuteczna stymulacja ruchowa występuje w okresach przyśpieszonego rozwoju danej zdolności motorycznej, to jest w tak zwanych okresach sensytywnych (Raczek, 1989). Znajomość występowania tychże okresów, w których zdolności motoryczne są szczególnie podatne na wytrenowanie, pozwala wyznaczyć podstawowe kierunki dotyczące realizacji procesu przygotowania sprawnościowego (Zając, 2000). Nie jest zatem rzeczą obojętną, kiedy rozpoczniemy kształtowanie poszczególnych zdolności motorycznych, bowiem nie jest możliwe rozwijanie ich z jednakowym skutkiem w każdym wieku (Sozański, 1981). Jednakże precyzyjne ustalenie tych okresów jest trudne ze względu na indywidualną zmienność rozwojową oraz wpływ wielu czynników nie zawsze podlegających kontroli, jak również dających się ująć w toku nawet bardzo złożonego badania (Wołkow, 1981).

Dynamika wzrastania poddanych analizie cech sprawności fizycznej ogólnej kształtuje się w obu porównywanych zespołach, sportowym i kontrolnym, chłopców i dziewcząt, na podobnym poziomie, z niewielką przewagą średnich przyrostów tychże cech na korzyść dzieci nieuprawiających akrobatyki sportowej. Różnice przeciętnych przyrostów porównywanych grup są tak nieznaczne, statystycznie nieistotne, że wysoki wyjściowy poziom sprawności fizycznej dzieci z klas akrobatycznych w porównaniu z ich rówieśnikami, utrzymuje się przez cały czas obserwacji, od pierwszego do ostatniego badania, na wysokim poziomie.

Przyczyn tegoż zjawiska poszukiwać można między innymi w optymalnym jak na ten okres rozwojem analizowanych cech u młodych akrobatów i akrobatek, jak również kierunkiem pracy szkoleniowej w akrobatyce sportowej. Przypomnieć należy, że średni poziom cech sprawności fizycznej ogólnej prezentowany przez dzieci z klas sportowych był bardzo wysoki i najprawdopodobniej optymalny dla potrzeb treningowych.

W przypadku próby biegu wahadłowego $10 \times 5 \mathrm{~m}$, której średnie wyniki u akrobatów i akrobatek są nieco niższe aniżeli ich rówieśników, obserwujemy sytuację nieco inną jak w przypadku wcześniej omawianych cech sprawności fizycznej. Z wiekiem przeciętne różnice rocznych przyrostów tej cechy są coraz większe, jednakże tym razem na korzyść dzieci uprawiających akrobatykę sportową. Bieg wahadłowy $10 \times 5 \mathrm{~m}$ jest próbą badającą równocześnie dwie cechy: szybkość i zwinność. W badanym w niniejszej pracy okresie ontogenezy cechy te charakteryzują się zbliżonymi torami rozwojowymi. Niższe średnie wyniki tejże próby u młodych adeptów akrobatyki sportowej w porównaniu z wynikami ich kolegów i koleżanek można by na tą chwilę uzasadnić wzrostem zaburzeń koordynacji ciała, wynikających z nagłych zmian proporcji ciała i przemieszczania się środka ciężkości ku górze (Osiński 1991), co między innymi może utrudniać wykonywanie szybkich zmian kierunku ruchu w czasie biegu wahadłowego. 


\section{Wnioski}

1. Zwiększony poziom aktywności ruchowej, obejmujący systematyczne i ukierunkowane ćwiczenia fizyczne z zakresu wstępnego i podstawowego szkolenia w akrobatyce sportowej, nie ujawnił znaczących różnic w tempie rozwoju i dynamice wzrastania poszczególnych cech u dzieci z klas sportowych i kontrolnych.

2. Zaobserwowana tendencja wyższych średnich przyrostów badanych cech rozwoju fizycznego (dotycząca zwłaszcza cech długościowych), prowadzi do zmniejszania się dystansu dzielącego młodych akrobatów i akrobatki od ich rówieśników z klas porównawczych.

\section{Literatura}

Dancewicz T., 1999, Efekty gimnastyków osiągnięte w 3-letnim procesie treningowym w wieku 7-10 lat, dysertacja doktorska, AWF, Gdańsk.

Drozdowski S., Drozdowski Z., 1975, Pomiar sprawności fizycznej ogólnej i specjalnej, Skrypty, nr 24, Wydawnictwo AWF w Poznaniu, Poznań.

Drozdowski Z., 1975, Rozwój fizyczny i sprawność fizyczna dzieci ziem północno-zachodnich, Monografie, nr 59, Wydawnictwo AWF w Poznaniu, Poznań.

Drozdowski Z., 1998, Antropometria w wychowaniu fizycznym, Podręczniki, nr 24, Wydawnictwo AWF w Poznaniu, Poznań.

Drozdowski Z., 2002, Antropologia dla nauczycieli wychowania fizycznego, Podręczniki, nr 37, Wydawnictwo AWF w Poznaniu, Poznań.

Firak R., 2003, Modelowe predyspozycje somatyczne czołowych zawodniczek świata w akrobatyce sportowej, dysertacja doktorska, AWF, Poznań.

Grabowski H., Szopa J., 1991, EUROFIT Europejski Test Sprawności Fizycznej, Wydawnictwo Skryptowe, nr 103, Wydawnictwo AWF, Kraków.

Kochanowicz K., 1998, Kompleksowa kontrola w gimnastyce sportowej, Wydawnictwo AWF, Gdańsk.

Kruczkowski D., 1998, Dobór i selekcja na etapie wszechstronnego i ukierunkowanego treningu chłopców w wieku 7-10 lat uprawiających gimnastykę sportową, dysertacja doktorska, AWF, Poznań.

Malinowski A., Strzałko J. (red.), 1985, Antropologia, Wydawnictwo Naukowe UAM, Poznań.

Osiński W., 1998, Tendencje w tworzeniu testów sprawności fizycznej w ramach koncepcji „health - related fitness”, „Antrpopmotoryka”, nr 17, s. 175.

Osiński W., 1991, Zagadnienia motoryczności człowieka, Skrypty, nr 66, Wydawnictwo AWF w Poznaniu Poznań.

Pawłucki A., 1972, Z aktualnych prac Międzynarodowego Kongresu do spraw Standaryzacji Testów Sprawności Fizycznej, „Kultura Fizyczna”, nr 1.

Przewęda R., 1985, Uwarunkowania poziomu sprawności fizycznej polskiej młodzieży szkolnej, Z Warsztatów Badawczych AWF, Wydawnictwo AWF, Warszawa.

Raczek J., 1986, Szkolenie młodzieży w systemie sportu wyczynowego, Wydawnictwo AWF, Katowice.

Raczek J., 1989, Teoria motoryczności (antropomotoryka) w systemie nauk o kulturze fizycznej, „Antropomotoryka", nr 1, s. 5-18.

Sozański H., 1981, Sport dzieci i młodzieży - poglądy i kontrowersje, „Sport Wyczynowy”, nr 8-9, s. $15-27$.

Szopa J., Żak S., 1986, Zmiany sprawności fizycznej dzieci i młodzieży Krakowa w latach 1974-1983 na tle trendu sekularnego wysokości ciała, „Wychowanie Fizyczne i Sport”, nr 1, s. 39-53. 
Tanner J.M., Cameron N., 1980, Investigation of the mid-growth spurt in height, weight and limb circumferences in single year velicity data from the London 1966-1967 growth survey, „Annals of Human Biology", vol. 7, s. 565-577.

Tanner J.M., Hughes P.C.R., Whitehouse R.H., 1981, Radiographically determined widths of bone, muscle and fat the upper arm and calf from age 3-18 years, „Annals of Human Bilogy”, vol. 8, s. 495-517.

Wolański N., 1975, Metody kontroli i normy rozwoju dzieci i młodzieży, PZWL, Warszawa.

Wolański N., 1983, Rozwój biologiczny człowieka, PWN, Warszawa.

Wołkow W.M., 1981, Biologiczne i środowiskowe uwarunkowania uzdolnień ruchowych, Sport Wyczynowy $\mathrm{nr} 7, \mathrm{~s} .26-50$.

Zając A., 2000, Przygotowanie sprawnościowe i psychiczne zawodnika, (w:) I. Ryguła (red.), Elementy teorii, metodyki, diagnostyki i optymalizacji treningu sportowego, Wydawnictwo AWF, Katowice, s. $135-234$.

Ziemilska A., 1984, Uwarunkowania szkolenia sportowego dzieci i młodzieży, „Sport Wyczynowy”, nr 4, s. 19-23.

Ziemilska A., 1984, Wpływ intensywności treningu gimnastycznego na rozwój somatyczny i dojrzewanie dzieci, Studia i Monografie AWF, Wydawnictwo AWF, Warszawa. 